\title{
Source contributions to 2012 summertime aerosols in the Euro-Mediterranean region
}

\author{
G. Rea $^{1}$, S. Turquety ${ }^{1}$, L. Menut ${ }^{1}$, R. Briant ${ }^{1}$, S. Mailler ${ }^{1}$, and G. Siour ${ }^{2}$ \\ ${ }^{1}$ Laboratoire de Météorologie Dynamique, UMR CNRS 8539, Université Pierre et Marie Curie - Paris 6, \\ ENPC, Ecole Polytechnique, Palaiseau, France \\ ${ }^{2}$ Laboratoire Inter-Universitaire des Systèmes Atmosphériques, UMR CNRS 7583, Université Paris Est \\ Créteil et Université Paris Diderot, Institut Pierre Simon Laplace, Créteil, France \\ Correspondence to: G. Rea (geraldine.rea@1md.polytechnique.fr)
}

Received: 2 February 2015 - Published in Atmos. Chem. Phys. Discuss.: 18 March 2015

Revised: 11 June 2015 - Accepted: 3 July 2015 - Published: 21 July 2015

\begin{abstract}
In the Mediterranean area, aerosols may originate from anthropogenic or natural emissions (biogenic, mineral dust, fire and sea salt) before undergoing complex chemistry. In case of a huge pollution event, it is important to know whether European pollution limits are exceeded and, if so, whether the pollution is due to anthropogenic or natural sources. In this study, the relative contribution of emissions to surface $\mathrm{PM}_{10}$, surface $\mathrm{PM}_{2.5}$ and total aerosol optical depth (AOD) is quantified. For Europe and the Mediterranean regions and during the summer of 2012, the WRF and CHIMERE models are used to perform a sensitivity analysis on a $50 \mathrm{~km}$ resolution domain (from $-10^{\circ} \mathrm{W}$ to $40^{\circ} \mathrm{E}$ and from $30^{\circ} \mathrm{N}$ to $55^{\circ} \mathrm{N}$ ): one simulation with all sources (reference) and all others with one source removed. The reference simulation is compared to data from the AirBase network and two ChArMEx stations, and from the AERONET network and the MODIS satellite instrument, to quantify the ability of the model to reproduce the observations. It is shown that the correlation ranges from 0.19 to 0.57 for surface particulate matter and from 0.35 to 0.75 for AOD. For the summer of 2012, the model shows that the region is mainly influenced by aerosols due to mineral dust and anthropogenic emissions (62 and 19\%, respectively, of total surface $\mathrm{PM}_{10}$ and 17 and $52 \%$ of total surface $\mathrm{PM}_{2.5}$ ). The western part of the Mediterranean is strongly influenced by mineral dust emissions ( $86 \%$ for surface $\mathrm{PM}_{10}$ and $44 \%$ for $\mathrm{PM}_{2.5}$ ), while anthropogenic emissions dominate in the northern Mediterranean basin (up to $75 \%$ for $\mathrm{PM}_{2.5}$ ). Fire emissions are more sporadic but may represent $20 \%$ of surface $\mathrm{PM}_{2.5}$, on average, during the period near local sources. Sea salt mainly
\end{abstract}

contributes for coastal sites (up to $29 \%$ ) and biogenic emissions mainly in central Europe (up to $20 \%$ ).

The same analysis was undertaken for the number of daily exceedances of the European Union limit of $50 \mu \mathrm{g} \mathrm{m}^{-3}$ for $\mathrm{PM}_{10}$ (over the stations), and for the number of daily exceedances of the WHO recommendation for $\mathrm{PM}_{2.5}$ $\left(25 \mu \mathrm{g} \mathrm{m}^{-3}\right)$, over the western part of Europe and the central north. This number is generally overestimated by the model, particularly in the northern part of the domain, but exceedances are captured at the right time. Optimized contributions are computed with the observations, by subtracting the background bias at each station and the specific peak biases from the considered sources. These optimized contributions show that if natural sources such as mineral dust and fire events are particularly difficult to estimate, they were responsible exclusively for 35.9 and $0.7 \%$, respectively, of the exceedances for $\mathrm{PM}_{10}$ during the summer of 2012. The $\mathrm{PM}_{25}$ recommendation of $25 \mu \mathrm{g} \mathrm{m}^{-3}$ is exceeded in $21.1 \%$ of the cases because of anthropogenic sources exclusively and in $0.02 \%$ because of fires. The other exceedances are induced by a mixed contribution between mainly mineral dust (49.5-67\% for $\mathrm{PM}_{10}$ exceedance contributions, 4.4-13.8\% for $\mathrm{PM}_{2.5}$ ), anthropogenic sources $(14.9-24.2 \%$ and $46.3-$ $80.6 \%)$, biogenic sources $(4.1-15.7 \%$ and $12.6-30 \%)$ and fires $(2.2-7.2 \%$ and $1.6-12.4 \%)$. 


\section{Introduction}

Numerous studies have shown the deleterious impact of particulate matter (PM) air pollution on human health. In particular, small particles, $\mathrm{PM}_{10}$ and $\mathrm{PM}_{2.5}$ (particulate matter with an aerodynamic diameter lower than 10 and $2.5 \mu \mathrm{m}$, respectively), enhance cardiopulmonary mortality and morbidity (Katsouyanni et al., 1997; Boldo et al., 2006; Pope and Dockery, 2006) due to their deeper penetration into the respiratory system.

Beyond these concerns, aerosol quantification is needed to evaluate its contribution to climate change. PM have a direct impact due to the absorption and scattering of solar radiation, the so-called "aerosol direct effect", as well as an indirect impact due to their role as cloud condensation nuclei (Yu et al., 2006; Carslaw et al., 2010; Stocker et al., 2013). Absorbing aerosols have also a "semi-direct effect" on cloud evaporation and cloud cover (Hansen et al., 1997).

Monitoring particulate matter ambient concentrations is thus an important issue for regional air quality and climate, and has become a key concern for pollution regulations in the past decade. Therefore, a correct understanding and quantification of aerosol formation and evolution is required.

The Mediterranean region is heavily influenced by numerous anthropogenic and natural aerosol sources and is often exposed to air pollution (Monks et al., 2009). Those sources, combined with complex interactions between atmospheric dynamics, geographical features and land-sea temperature gradients (Lionello et al., 2006), lead to an European aerosol load maximum (Textor et al., 2006; Putaud et al., 2010). Meteorological conditions hold a key role in the development of aerosol-related pollution events (Millán et al., 2002). Being in a transitional zone between the subtropical high-pressure belt and the mid-latitude westerlies and low pressure systems, the Mediterranean region is characterized by hot, dry summers and mild, wet winters. These meteorological patterns govern the transport of aerosols released from various sources around the Mediterranean region and lead to a maximum aerosol load during the summer (Monks et al., 2009; Nabat et al., 2013). Moreover, a mixture of different sources is usually observed due to the long-range transport of the associated particles (Dall'Osto et al., 2010; Gerasopoulos et al., 2011; Boselli et al., 2012). Due to these complex characteristics, the specific impact of each aerosol source cannot be easily assessed.

The region is impacted by local emissions from anthropogenic activities and by biogenic emissions of precursors of aerosol formation. Most of $\mathrm{PM}_{2.5}$ exceedances are due to primary pollution but these are enhanced by the production of secondary aerosols (Koçak et al., 2007). For instance, Sartelet et al. (2012) found that Secondary Organic Aerosol (SOA) formation over Europe is strongly impacted by biogenic emissions (72-88\%) in addition to anthropogenic emissions of precursors. Another study by Im and Kanakidou (2012) showed that regional anthropogenic emissions contributes to $47 \%$ of $\mathrm{PM}_{2.5}$ in the eastern basin (Greece, Turkey) in summer, with $4 \%$ from Istanbul.

Moreover, the long-range transport of mineral dust from North Africa significantly affects PM concentration throughout the region. Several studies of available observations show that the $\mathrm{PM}_{10}$ European Union air quality standard ( $50 \mu \mathrm{g} \mathrm{m}^{-3}$, daily average) is exceeded at many locations around the basin because of a combination of mineral dust and anthropogenic pollutants from local sources (Gerasopoulos et al., 2006; Gobbi et al., 2007; Koçak et al., 2007; Rodriguez et al., 2007; Kaskaoutis et al., 2008). Mineral dust outbreaks, although transported through the Mediterranean sea during all seasons, are more frequent in spring and summer, where dust plumes are transported through the Atlantic and reach mainly and regularly the western part of the region (Moulin et al., 1998; Israelevich et al., 2012; Salvador et al., 2014; Ripoll et al., 2015). In summer, mineral dust aerosols are also observed over central Europe (Israelevich et al., 2012; Salvador et al., 2014).

Another important source of PM in the Mediterranean basin is sea salt, which can account for instance in Erdemli (eastern Mediterranean coast) for up to $50 \%$ of $\mathrm{PM}_{10}$ concentration threshold exceedances (Koçak et al., 2007).

Vegetation fires (recurrent in eastern and southern Europe during spring and summer) are also a significant additional source of PM (Turquety et al., 2014), with consequences on air quality throughout the basin (Pace et al., 2005; Hodzic et al., 2007; Barnaba et al., 2011).

The natural emissions from fires and mineral dust are particularly difficult to quantify accurately due to their intense and sporadic nature resulting in large spatial and temporal variability. Several projects have been undertaken over the past years to improve the understanding and the quantification of particulate pollution over the Mediterranean region. Among those, the ChArMEx international program (Chemistry-Aerosol Mediterranean Experiment, http: //charmex.lsce.ipsl.fr), allowed the settlement of several additional observation sites as well as intensive measurement campaigns during the summers of 2012, 2013 and 2014. In 2012, the ChArMEx/TRAQUA (TRansport and Air QuAlity) experiment allowed the characterization of a very intense dust transport event measured at the end of June over the western Mediterranean (Nabat et al., 2015). In addition, several large fires were reported during the summer of 2012, more particularly in the Balkans (Anttila et al., 2015) and in Spain in July (Gómez-Amo et al., 2013).

The majority of the studies previously cited have been made at specific experimental sites and sometimes for specific case studies or sources. The purpose of our analysis is to estimate the relative contributions of this diversity of sources, and thus to draw a regional context of aerosol pollution during the summer of 2012 in the framework of the ChArMEx program.

Aerosol optical properties are important to characterize aerosols for air pollution monitoring. They are needed to es- 
timate the radiative effects, which have themselves an impact on photochemistry by modifying the photolysis rates (Mailler et al., 2015). Moreover, optical properties are directly related to aerosol particle concentration, type and size. The observations of aerosol optical properties from remote sensing instruments thus provide an important complement to the surface PM databases. In particular, extensive measurements of the aerosol optical depth (AOD), characterizing the light extinction associated with the aerosols along the full vertical column, are provided by the surface AErosol RObotic NETwork (AERONET; http://aeronet.gsfc. nasa.gov) and by several satellite-based instruments, allowing a very good spatial and temporal coverage.

In addition to the analysis of surface and remote sensing observations, chemistry-transport models (CTMs) are required for the simulation of atmospheric composition and the understanding of physico-chemical processes. Model validation or inter-comparisons have shown that, although the modeling of ozone or other gases has been improved in the past years, the modeling of PM is still a concern, with a persistent underestimation of $\mathrm{PM}_{10}$ for the majority of the CTMs (Roustan et al., 2010; Solazzo et al., 2012; Im et al., 2015). Moreover, $\mathrm{PM}_{2.5}$ is also overestimated when $\mathrm{PM}_{10}$ is improved, although the biases on $\mathrm{PM}_{2.5}$ are lower than those on $\mathrm{PM}_{10}$. Even though emissions probably constitute a significant source of uncertainty, the uncertainty in modeled PM concentrations linked to the parameterization choices (vertical diffusion, number of levels, deposition, etc.) and to the meteorological fields can be for instance higher than the uncertainty linked to PM anthropogenic and biogenic emissions (Sartelet et al., 2012). The uncertainty in PM concentrations leads to uncertainties in the simulated aerosol optical properties and AOD (Péré et al., 2010; Curci et al., 2014), in addition to uncertainties in the calculation of optical properties (refractive indices, assumptions on aerosol mixing, density).

This paper provides an analysis of the main contributions of aerosol sources to both surface PM and AOD in the Mediterranean region using the CHIMERE state-of-the-art regional CTM (Menut et al., 2013). This paper aims at estimating the contribution of each source in Europe and the Mediterranean basin, to provide a description of the zones of influence of given sources on regional air pollution.

After an evaluation of the model's performance through comparisons to observations from surface networks and remote sensing, a sensitivity analysis is conducted on the case study of the summer of 2012 (June-July-August). This time period allows an analysis including all sources (fires and dust outbreaks notably occurred during this period). Estimations of the relative contributions of the main aerosol sources to the aerosol load in the Mediterranean area is provided. Section 2 describes particulate pollution during the summer of 2012 based on the available observations of surface PM and AOD. Section 3 presents the tools and methodology used in this paper. The model is evaluated against observations in Sect. 4, and sensitivity simulations are discussed in Sects. 5
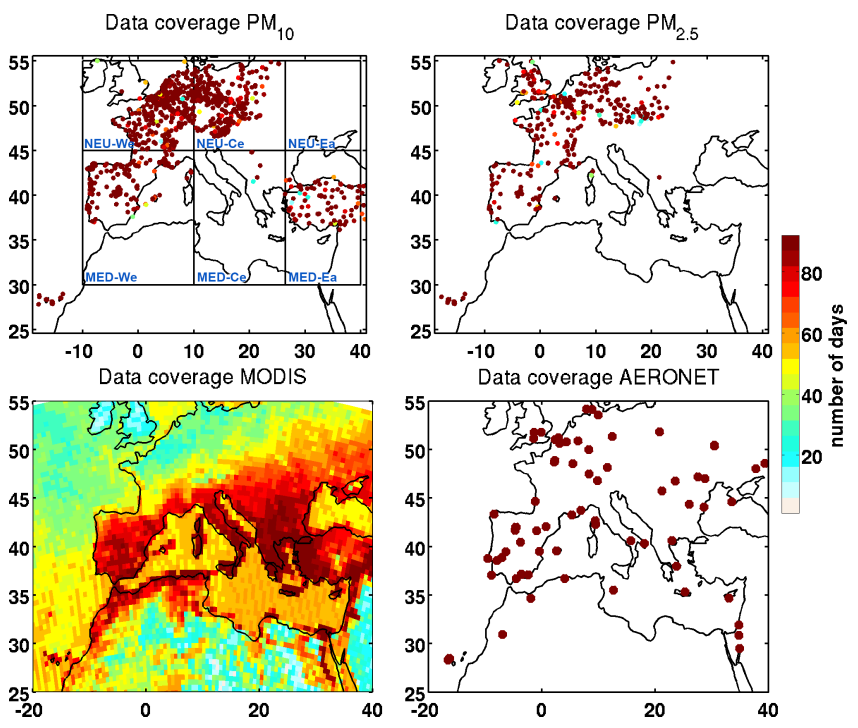

Figure 1. Data coverage during the summer of 2012 (1 June to 31 August, 92 days) for each observation data set, i.e., the number of days with measurements from AirBase stations with $\mathrm{PM}_{10}$ and $\mathrm{PM}_{2.5}$ values, AERONET stations and MODIS data with values for the AOD at 500 and $550 \mathrm{~nm}$, respectively.

and 6, where an estimation of contributions to surface PM and AOD and to air quality threshold exceedances is also assessed.

\section{Presentation and analysis of observations}

Aerosol quantification from 1 June to 31 August over the region is analyzed in this section using observations of both surface PM concentrations and AOD, which provide an overview of the main polluted regions and the temporal variability of aerosol concentrations.

The domain was divided into six sub-regions, which present different characteristics in terms of sources, population density as well as meteorological patterns, which are reflected in the observations. The acronyms MED and NEU represent, respectively, all the Mediterranean basin and the northern European part of the domain. MED and NEU regions are divided into western, central and eastern zones (MED-We, MED-Ce, MED-Ea and NEU-We, NEU$\mathrm{Ce}, \mathrm{NEU}-\mathrm{Ea})$. The delimitations of the regions are indicated in Table 1 and Fig. 1.

\subsection{Surface PM}

Surface PM concentrations from the model are evaluated through comparisons to $\mathrm{PM}_{2.5}$ and $\mathrm{PM}_{10}$ observations from the European Air quality database (AirBase) of the European Environment Agency (http://acm.eionet.europa.eu/ databases/airbase). This database provides air quality monitoring data and information from 38 countries around 
Table 1. Coordinates of the simulation domain and sub-domains used for further analysis.

\begin{tabular}{llrrrr}
\hline Domain & Acronym & \multicolumn{2}{c}{$\begin{array}{c}\text { Longitude }\left({ }^{\circ} \mathrm{E}\right) \\
\text { Minimum }\end{array}$} & $\begin{array}{c}\text { Latitude }\left({ }^{\circ} \mathrm{N}\right) \\
\text { Maximum }\end{array}$ & Minimum \\
& & -52.6 & 68.6 & -4.3 & 56.4 \\
\hline Full domain & & -10.0 & 10.0 & 45.0 & 55.0 \\
Northern Europe - west & NEU-We & 10.0 & 26.0 & 45.0 & 55.0 \\
Northern Europe - center & NEU-Ce & 26.0 & 40.0 & 45.0 & 55.0 \\
Northern Europe - east & NEU-Ea & -10.0 & 10.0 & 30.0 & 45.0 \\
Mediterranean basin - west & MED-We & 10.0 & 26.0 & 30.0 & 45.0 \\
Mediterranean basin - center & MED-Ce & 26.0 & 40.0 & 30.0 & 45.0 \\
Mediterranean basin - east & MED-Ea & 26.0 & & & \\
\hline
\end{tabular}

Europe, and includes more than 6000 stations providing hourly and daily measurements. The diversity of instruments and sampling, associated with certain meteorological conditions (relative humidity) contribute to the uncertainty of the database. The standard error of the AirBase network PM measurements is better than $25 \%$. Only rural and background stations are included in the present paper. Indeed, urban sites being strongly influenced by local sources, they are not relevant for this analysis of the regional trends and budget of pollution. This reduces the number of stations to 927 for $\mathrm{PM}_{10}$ and 316 for $\mathrm{PM}_{2.5}$. Two additional rural stations located in Corsica in the framework of the ChArMEx project are also taken in consideration (Venaco and Ersa).

The average concentration from 1 June to 31 August 2012 at the $\mathrm{PM}_{10}$ stations is shown in Fig. 2, with the number of days with data shown in Fig. 1. Almost all stations present data every day of the studied time period. Most of the stations are concentrated in the central north of the domain, so that the analysis over the Mediterranean Sea itself and around most of its coasts is not possible.

The observations show that some regions are recurrently affected by pollution. These correspond to most of the Mediterranean coastline (stations in Spain, south of France), with monthly averaged concentrations of $\mathrm{PM}_{10}$ up to $40 \mu \mathrm{g} \mathrm{m}^{-3}$ and maxima around $200 \mu \mathrm{g} \mathrm{m}^{-3}$. The Po Valley and the Benelux are also affected by high levels (up to $200 \mu \mathrm{g} \mathrm{m}^{-3}$ ) as well as eastern Europe.

For example, high values of PM are detected in Farollilo near Salamanca, Spain (Fig. 3) at the end (27-28) of June (with a concentration up to $120 \mu \mathrm{g} \mathrm{m}^{-3}$ ), and end of July and above $80 \mu \mathrm{g} \mathrm{m}^{-3}$ during August (around 10 and 18-19). The level of PM in this area remains high (around $40 \mu \mathrm{g} \mathrm{m}^{-3}$ for daily mean) during the whole time period. Observations in the south of France show lower temporal variability with concentrations from 10 to around $50 \mu \mathrm{g} \mathrm{m}^{-3}$. Some sporadic hourly values (not shown) reach more than $100 \mu \mathrm{g} \mathrm{m}^{-3}$ around 20-21 June, at the end of July and the end of August. For example, at the station located in Miramas in the south of France, hourly values reach more than $250 \mu \mathrm{g} \mathrm{m}^{-3}$ (daily mean value of $80 \mu \mathrm{g} \mathrm{m}^{-3}$ ) around 20 June, during the end of July, and during the beginning of August.
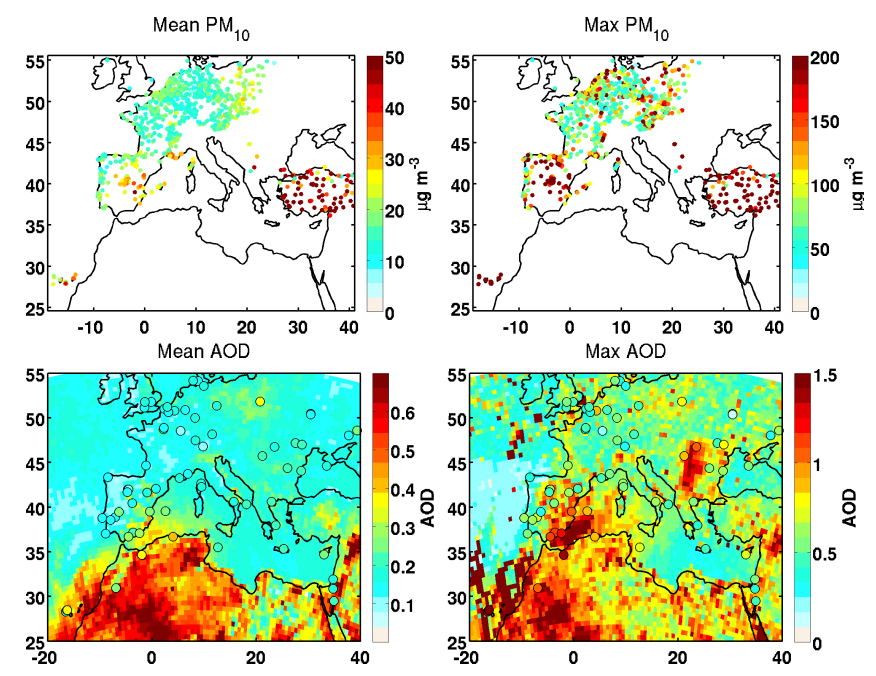

Figure 2. Summer 2012 (1 June to 31 August) daily average for surface $\mathrm{PM}_{10}$ concentrations from the AirBase network and Ersa and Venaco stations (upper left) and aerosol optical depth at 550 and $500 \mathrm{~nm}$, respectively, from MODIS instrument and AERONET stations (bottom left). Daily maximum over the period is shown in the upper right panel for surface $\mathrm{PM}_{10}$ concentrations and the bottom right panel for aerosol optical depth.

Eastern Europe is also affected by high concentrations, as shown for example by the Lomza station in Poland, with peak values around 30 June (up to $90 \mu \mathrm{g} \mathrm{m}^{-3}$ ), at the end of July (above $300 \mu \mathrm{g} \mathrm{m}^{-3}$ for Mragowo, Poland) and during the second half of August (up to $100 \mu \mathrm{g} \mathrm{m}^{-3}$ ).

\subsection{Aerosol optical depth (AOD)}

In addition to surface PM, remote sensing observations of AOD, which provides information on the column integrated aerosol load, are analyzed. Both surface remote sensing from AERONET and satellite observations from the Moderate Resolution Imaging Spectroradiometer (MODIS) are used.

AERONET is an optical ground-based aerosol-monitoring network, composed of spectral radiometers. It allows measurements of AOD every 15 min at 8 wavelengths (centred between 340 and $1020 \mathrm{~nm}$ ). With more than one hundred sta- 

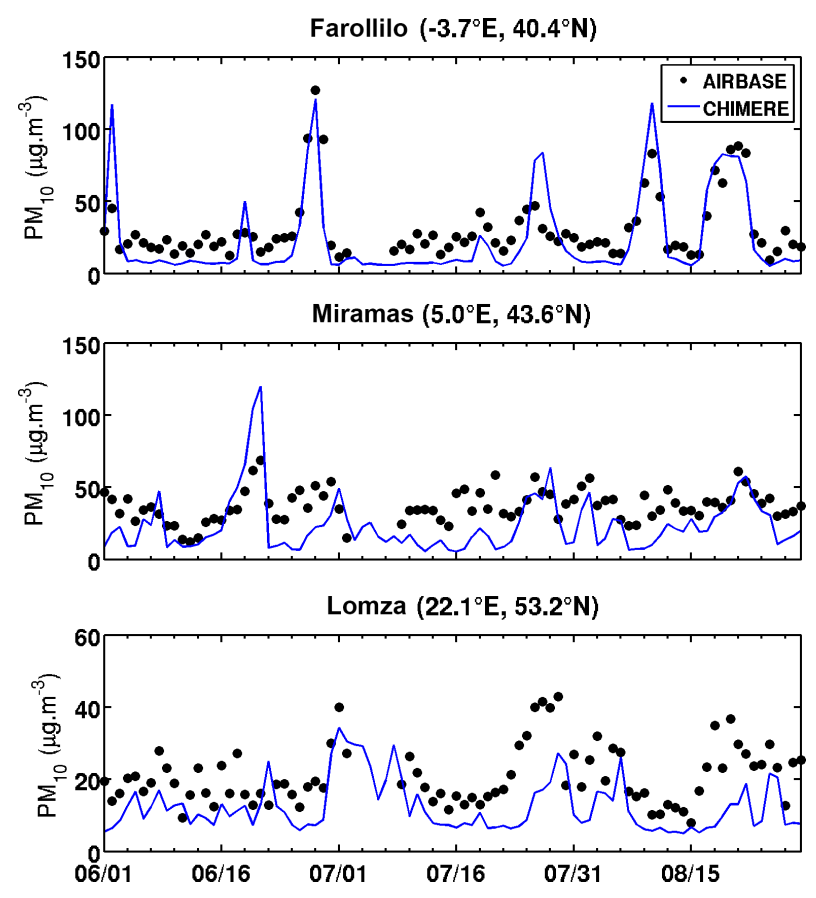

Figure 3. Time series from 1 June to 31 August of daily mean surface $\mathrm{PM}_{10}$ concentrations from three stations of the AirBase network. The top station is located near Salamanca in Spain, middle is in Miramas in the south of France, and bottom is in Lomza in Poland. The corresponding simulated CHIMERE concentrations (spatially co-localized) are also indicated (blue line).

tions in the world, the network is widely used for the validation of model simulations and satellites observations. The main product examined here is the level 2.0, cloud-screened and quality assured, total AOD at $550 \mathrm{~nm}$ retrieved from the ground-based AERONET sun photometers.

The estimated precision of the direct AOD measurements is $\sim 0.01$ (at $440 \mathrm{~nm}$ ) for a recently calibrated instrument (Holben et al., 1998), and the uncertainties are well documented (Dubovik et al., 2000). During the period of the simulation, data from 53 stations of the network are available within the domain, with values each day of the summer of 2012 (Fig. 1).

Surface site measurements do not allow a full regional evaluation, particularly around the Mediterranean basin, which is poorly covered. Satellite observations therefore offer a good complement. MODIS is carried on board the Terra and Aqua satellites (NASA) and enables a daily nearglobal coverage of the Earth with its large swath of almost $2330 \mathrm{~km}$. The satellites cross the equator at about 10:30 and 13:30 UTC (ascending node), respectively. The measurements over 36 spectral bands (from 0.41 to $15 \mu \mathrm{m}$ ) allow the retrieval of many aerosols properties. For this study, the aerosol products MOD04 (for Terra) and MYD04 (for Aqua) from L2 5.2 collection data are used (Remer et al., 2006). It includes daily AOD at $550 \mathrm{~nm}$, as well as the Deep-
Blue AOD (Sayer et al., 2013) that provides AOD over bright land areas (especially useful here for North Africa). They are available at $10 \mathrm{~km} \times 10 \mathrm{~km}$ resolution. The expected error for the AOD is $\pm 0.05 \pm 0.15 \mathrm{AOD}$ over land and $\pm 0.03 \pm 0.05$ AOD over ocean, with a good agreement with ground based measurements (Remer et al., 2005).

The data coverage over the studied time period is shown in Fig. 1. The Mediterranean basin presents AOD values almost every day. For eastern Europe and the Balkans, fewer AERONET or AirBase stations are available. The north of Europe is under-represented during the period, due to recurrent clouds in the area.

The AOD at $550 \mathrm{~nm}$ from the AERONET and MODIS data sets have been compared over the studied region and time period. Both data sets are coherent in variability and levels (not shown): correlation coefficients range from 0.71 in MED-Ea to 0.96 in NEU-We and there is a slight overestimation of MODIS compared to AERONET measurements (mean fractional bias of $7 \%$ on average).

Spatial patterns of AOD over the region are similar to the ones observed in terms of surface PM concentrations (Fig. 2, bottom right panel), with high values at the south of the domain (up to 2 for North Africa and all around the Mediterranean Sea on a seasonal average), the Po Valley and northern Europe (up to 1.2). MODIS allows a better coverage than surface measurements in some regions, like North Africa, the Mediterranean Sea, the Atlantic Ocean, the Balkans and the eastern part of the domain (eastern Europe, Middle East, etc.) For example, large values of AOD, from 1 to 2, are observed with MODIS in the Balkans.

Time series for three AERONET stations are shown in Fig. 4. Clear enhancements are detected above Granada at the end of June (19 and 25-26 June), and in August (2, 8-9 and 18 August). The Timisoara station shows values around 1 on 24 August for both MODIS and AERONET. Finally, observations at Belsk in Poland show lower values but a notable peak around 1 July.

A comparison of these AOD observations for 2012 against the climatology from Nabat et al. (2013), which includes the AOD from 2003 to 2009 using both model and satellitederived AOD products, indicates that this summer was in the average regarding the aerosol load. Exceptions appears in June when the AOD was higher than the climatology in North Africa and over the Atlantic Ocean near North African coasts (due to a strong dust event Nabat et al., 2015), and in August with high values over the Balkans and over the Mediterranean close to the Spanish coastline. There are also higher punctual values in Spain in July. This comparison shows that the period was affected by air pollution from different sporadic events.

From this analysis, several regions and time periods with enhanced aerosol concentrations are identified during the summer of 2012. North Africa and the western Mediterranean basin were regularly affected by the highest aerosol loads, with extreme peaks around 26 June and three times 


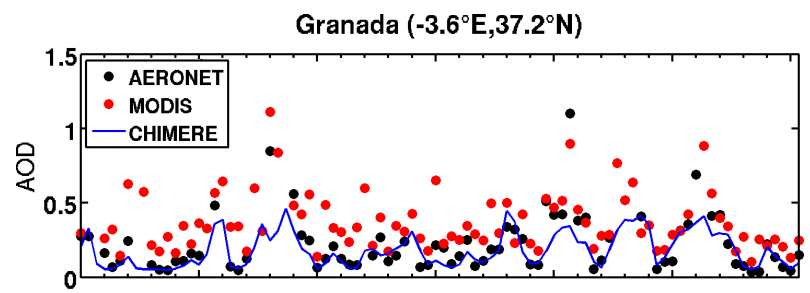

Timisoara $\left(21.2^{\circ} \mathrm{E}, 45.7^{\circ} \mathrm{N}\right)$

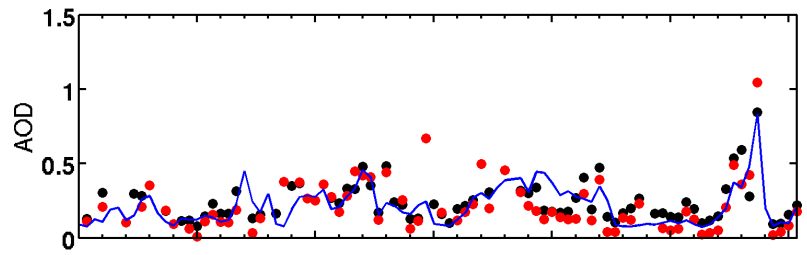

Belsk $\left(20.8^{\circ} \mathrm{E}, 51.8^{\circ} \mathrm{N}\right)$

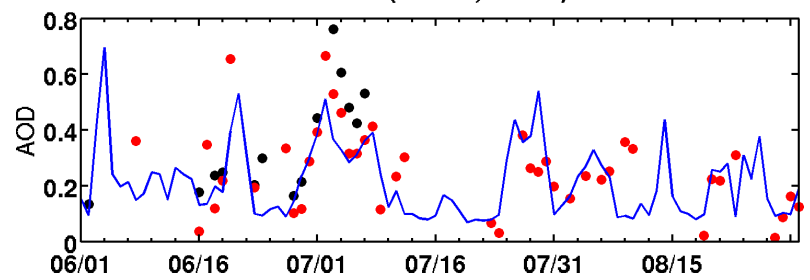

Figure 4. Time series from 1 June to 31 August of the daily AOD at $500 \mathrm{~nm}$ from three AERONET stations. Top station is Granada in Spain, middle is Timisoara in Romania, and bottom is Belsk in Poland. Values from MODIS at $550 \mathrm{~nm}$ are also indicated in red dots at these stations, as well as the simulated spatially co-localized $550 \mathrm{~nm}$ AOD from CHIMERE (blue line).

in August (daily mean of around $130 \mu \mathrm{g} \mathrm{m}^{-3}$ for $\mathrm{PM}_{10}$ and AOD around 1). Eastern Europe appears to show other influences with high concentrations of surface PM at the end of June, the end of July and the end of August (daily mean of $40 \mu \mathrm{g} \mathrm{m}^{-3}$ for $\mathrm{PM}_{10}$, AOD up to 0.8). In the Balkans, MODIS also observed relatively high AOD (around 1) at the end of August.

\section{Modeling tools}

The sensitivity of aerosol concentrations in the region to each source is evaluated using the CHIMERE regional CTM, driven by meteorological simulations performed using the mesoscale non-hydrostatic Weather Research and Forecasting (WRF) model.

The analysis is focused on the summer of 2012 ( 1 June to 31 August 2012), with a 10-day spin-up. The simulation domain is chosen to include all contributing sources around the basin (including North Africa until the Sahel, a part of the Atlantic Ocean, and eastern and northern Europe). A Lambert conformal projection is used with a constant horizontal resolution of $50 \mathrm{~km} \times 50 \mathrm{~km}$. The domain is represented in Fig. 5.
This section introduces the models used, their configuration for this analysis, the emissions databases as well as the numerical approach used.

\subsection{The WRF meteorological model}

The meteorological fields are simulated using the WRF model version 3.5.1 (Skamarock et al., 2008), on a $50 \mathrm{~km}$ horizontal grid (same horizontal domain described above). The simulation has been performed with boundary conditions and nudging from the meteorological analysis data of NCEP (Kalnay et al., 1996), provided on a regular $1.125^{\circ} \times 1.125^{\circ}$ grid.

The model is used in its non-hydrostatic configuration. The vertical grid covers 30 levels from the surface to $50 \mathrm{hPa}$. The WRF Single-Moment 6-class (Hong and Lim, 2006) is used for microphysics, and RRTMG (Iacono et al., 2008) and the Dudhia schemes (Dudhia, 1989) are used for long and short wave radiation, respectively. The surface layer scheme is based on the Monin-Obukhov scheme (Janjic, 1996). Surface planetary boundary layer physics use the Noah Land Surface Model (Chen and Dudhia, 2001) and Yonsei University scheme (Hong et al., 2006), and the cumulus parameterization is based on the Kain-Fritsch scheme (Kain, 1993).

The WRF simulation outputs are then linearly interpolated on the vertical resolution of CHIMERE and used to diagnose additional parameters (e.g., boundary layer height, friction velocity). Both meteorology and chemical concentration output fields are provided at $1 \mathrm{~h}$ time intervals.

\subsection{The CHIMERE chemistry-transport model}

CHIMERE is an off-line regional CTM forced by emissions (see Sect. 3.3), meteorological fields (see Sect. 3.1) and boundary conditions. The model version chimere2014 (Menut et al., 2013) is used here on the $50 \mathrm{~km}$ horizontal resolution grid described above. The vertical discretization consists in 18 uneven levels in hybrid sigma-pressure coordinates, from the surface up to $200 \mathrm{hPa}$ and with 8 levels under $800 \mathrm{hPa}$.

The reduced chemical mechanism called MELCHIOR2 is used here and includes 44 species involved in almost 120 reactions. The list of species and reactions is provided in Menut et al. (2013). The aerosol module developed by Bessagnet et al. (2004) allows the simulation of primary particulate matter and secondary species: nitrates, sulfates, ammonium, primary organic matter (POM), secondary organic aerosol (SOA), elemental carbon (EC), marine aerosols and mineral dust. Their life cycle is represented with a complete scheme of nucleation, absorption, adsorption, desorption, coagulation, as well as wet and dry deposition and scavenging. The size distribution is simulated using a sectional representation, i.e., using five diameter bins: $40-150 \mathrm{~nm}, 150-630 \mathrm{~nm}, 630$ $2500 \mathrm{~nm}, 2.5-10 \mu \mathrm{m}$, and $10-40 \mu \mathrm{m}$. 

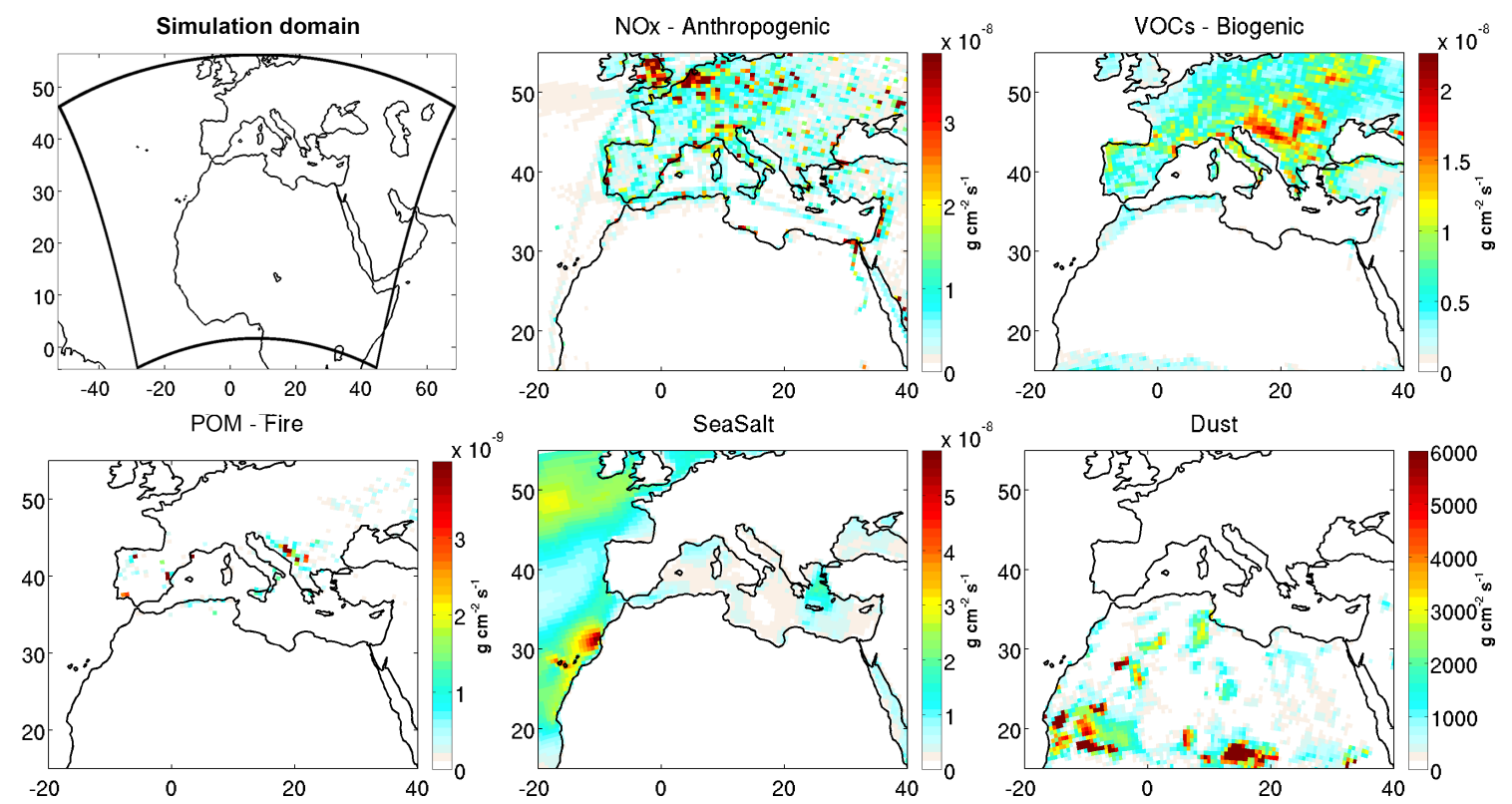

Figure 5. Total fluxes of different aerosol precursors or primary aerosol from each source averaged during the summer of 2012: anthropogenic emissions of nitrogen oxides $\left(\mathrm{NO}_{x}\right.$ ), biogenic emissions of volatile organic compounds (VOCs), fire emissions of primary organic matter $(\mathrm{POM})$, mineral dust and sea salt emissions.

Initial and boundary conditions are provided by 5-year monthly averaged simulations by the LMDZ-INCA global model for aerosols and trace gases (Folberth et al., 2006), and GOCART for mineral dust (Ginoux et al., 2001).

The photolysis rates are calculated online using the FastJX module, version 7.0b (Wild et al., 2000; Bian and Prather, 2002) as described in Menut et al. (2013). The module computes the actinic fluxes by resolving the radiative transfer in the modeled atmospheric column. The treatment of optical properties is made by taking into account absorption by tropospheric and stratospheric ozone, Rayleigh scattering, absorption by aerosols, and Mie diffusion by aerosols and by liquid- and ice-water clouds. The total AOD is also obtained from these calculations, with an internal mixing state assumption for aerosols, at five different wavelengths: 200, 300, 400, 600 and $1000 \mathrm{~nm}$ (Mailler et al., 2015). As the calculation of the photolysis rates is performed at each physical time step taking into account the actualized concentrations of ozone and aerosols, this methodology allows radiative feedback of aerosol and ozone concentrations on photolysis rates. In this study, the simulated AOD from CHIMERE at 500 and $550 \mathrm{~nm}$ are used and extracted using the Angström coefficient from the output wavelengths.

\subsection{Emissions}

This section briefly describes the databases used for both primary particulate matter emissions and the emission of gaseous precursors.

Anthropogenic emissions are the only emissions that can be controlled; their inventories are updated constantly to take into account precise emissions in scenario studies. In this paper, the EDGAR-HTAP_V2 inventory for the reference year 2010 is used. It uses HTAP (Hemispheric Transport of Air Pollution) annual total masses that include nationally reported emissions combined with regional scientific inventories, complemented with EDGARv4.3 data (http://edgar.jrc. ec.europa.eu/htap_v2/index.php?SECURE=123). The inventory provides global annual emissions for $\mathrm{CH}_{4}$, NMVOC, $\mathrm{CO}, \mathrm{SO}_{2}, \mathrm{NO}_{x}, \mathrm{NH}_{3}, \mathrm{PM}_{10}, \mathrm{PM}_{2.5}, \mathrm{BC}$ and $\mathrm{OC}$, with a resolution of $0.1^{\circ} \times 0.1^{\circ}$. The annual emitted masses are disaggregated into model species and mapped onto the specified grid. Hourly emissions are estimated by applying seasonal, daily and weekly factors depending on the SNAP (Selected Nomenclature for Air Pollution) sectors (Menut et al., 2012). Anthropogenic emissions represent 90 to $100 \%$ (among all other sources) of the regional emissions of $\mathrm{NO}_{x}, \mathrm{NH}_{3}$ and $\mathrm{SO}_{2}$, which are important precursors of inorganic aerosol formation. For example, the total fluxes of $\mathrm{NO}_{x}$ in the region for the summer of 2012 are shown in Fig. 5. Anthropogenic emissions (excluding forest fires) also amount to $53 \%$ of primary organic matter emissions, $81 \%$ of black carbon emissions, and $74 \%$ of other primary particulate matter emissions.

Biogenic emissions fluxes are calculated using the global Model of Emissions of Gases and Aerosols from Nature (MEGAN; Guenther et al., 2006) and affect six CHIMERE species (isoprene, $\alpha$-pinene, $\beta$-pinene, limonene, ocimene and NO). MEGAN is based on canopy-scale emission factors depending on the species. In their analysis of isoprene emissions over Europe, Curci et al. (2010) compared CHIMERE 
simulation to satellite observations and found that MEGAN isoprene emissions might be $40 \%$ higher over the Balkans, $20 \%$ too high over southern Germany, and $20 \%$ too low over Iberian Peninsula, Greece and Italy. In Fig. 5, showing the calculated total biogenic fluxes of VOCs in Europe and the Mediterranean basin during the summer of 2012, we can see that the majority of the emissions fluxes are located in the Balkans and eastern Europe, and in general in the northern European part of the domain.

Mineral dust emissions use fluxes calculation with the Marticorena and Bergametti (1995) parametrization for saltation and the optimized dust production model (Alfaro and Gomes, 2001; Menut et al., 2005) for sandblasting. The dust production model uses the model presented in Menut et al. (2013), which has been extended to be applicable to any region and not just North Africa (Briant et al., 2014). It uses new global soil and surface input data sets along with the global ASCAT/PARASOL aeolian roughness length data set (Prigent et al., 2012). Parameterizations for humidity (Fécan et al., 1999) and seasonal vegetation variation were included. Since long-range transport from North Africa affects strongly the Mediterranean basin and Europe, the simulation domain was chosen in order to include western Africa and the Sahel, known to be active mineral dust sources (Israelevich et al., 2002; Prospero et al., 2002). In Fig. 5, representing the mineral dust emissions computed for the study, the majority of them are located in this region. Transport from the Sahel band where the most active sources are found is mainly towards the Atlantic. Mineral dust particles are chemically inert in CHIMERE, but their size distribution is affected by wet and dry deposition. Dust emissions and deposition are strongly affected by meteorological fields, leading to large uncertainties (Menut et al., 2007, 2009).

Fire emissions are calculated using the APIFLAME v1.0 emissions model, described in Turquety et al. (2014), with a classical approach of multiplying the burned area by the fuel load consumed and the emission factors specific to the vegetation burned. Fire emissions are injected homogeneously onto the boundary layer for this study. This parametrization can lead to uncertainties on the results as it impacts the transport of polluted plumes. The uncertainties concerning fire emissions are high, due to the accumulation of uncertainties on the emission factors, the area burned, the type of vegetation, etc. The uncertainty in the daily carbon emission is estimated at $100 \%$ (Turquety et al., 2014), and using different inventories can lead to differences from -70 to $450 \%$ for outputs concentrations of CO (Daskalakis et al., 2015). The injection height can also be a source of uncertainty, as it can impact the transport pathway of a fire plume. Fires are the dominant source of primary organic matter, black carbon and other primary particulate matter in the MED-We (76, 34, and 58.6\%, respectively) and MED-Ce (89.2, 46.4, and $69.9 \%$, respectively) regions during the summer of 2012, where they occurred mainly in the Balkans and in the Iberian Peninsula (Fig. 5). A smaller fraction of gaseous precursors is also emitted by fires (between 9 and $15 \%$ for $\mathrm{NO}_{x}$ and $\mathrm{NH}_{3}$ in MED-Ce). The distribution of primary organic matter fire emissions is shown in Fig. 5. Regions affected by fires during this period are mostly located in the Balkans and in Spain.

The calculation of sea salt emissions is based on the Monahan (1986) scheme. Marine aerosols are produced from bubble bursting of whitecaps, generated by surface winds. The largest emissions occur over the Atlantic Ocean.

\subsection{Sensitivity analysis}

The CHIMERE CTM has been used to perform a number of sensitivity simulations, each with one source eliminated. The aim is to provide the approximate impact from the main different regional source types. A complete budget would require the consideration of transport from boundary conditions as an additional source as well as the different sinks (wet and dry deposition, outflow). However, our main objective is to quantify the relative contribution from natural sources (dust, sea salts, fires, biogenic emissions of precursors) inside the regional domain, since these emissions cannot be controlled by regulations. Only these sources and anthropogenic sources are thus considered.

All the results will be presented in terms of the difference between the reference simulation (all sources included) and the simulation in which the specific source is removed. For instance, to obtain the contribution of fire emissions to the concentration of a pollutant $[X]$, called $[X]_{\text {fire }}$, we computed

$[X]_{\text {fire }}=[X]_{\text {ref }}-[X]_{\text {without_fire_emissions }}$

The acronyms associated with the sensitivity simulations undertaken for the study are ANTH, BIOG, FIRE, DUST, and SALT for the baseline simulation minus the simulation without anthropogenic, biogenic, fire, mineral dust and sea salt emissions, respectively.

Note that the sum of all individual sources may not amount to the reference concentrations of PM due to non-linearities in chemical processes. However, PM sensitivity studies show that the main conclusions do not change with other methods such as source apportionment or direct decoupled sensitivity, if the formation of secondary species is not significant (Koo et al., 2007, 2009; Burr and Zhang, 2011).

In our study, the amount of $\mathrm{PM}_{2.5}$ and $\mathrm{PM}_{10}$ formed by non-linear processes can be evaluated in the reference simulation. Therefore, the relative contribution from SOA and nitrates, which will be most impacted by non-linearities, to the total PM concentrations is calculated. On average over the domain and for the reference simulation during the summer of 2012, $2.5 \%$ of total $\mathrm{PM}_{2.5}$ is composed of SOA, and $1.3 \%$ of nitrates. Contributions to total $\mathrm{PM}_{2.5}$ from the sensitivity simulations have been evaluated to 1.3 and $1.1 \%$ of SOA and nitrates, respectively, from anthropogenic sources, and $1.5 \%$ and maximum $0.01 \%$ of SOA and nitrates from bio- 
Table 2. Performance statistics for the simulation of hourly PM with CHIMERE (Mod.) compared to coincident surface station measurements (Obs.) during the summer of 2012.

\begin{tabular}{|c|c|c|c|c|c|c|c|c|c|}
\hline \multirow[t]{2}{*}{ Variable } & \multirow[t]{2}{*}{ Region } & \multirow{2}{*}{$\begin{array}{r}\text { Number } \\
\text { of stations }\end{array}$} & \multicolumn{2}{|c|}{ Mean $\left(\mu \mathrm{g} \mathrm{m}^{-3}\right)$} & \multirow[t]{2}{*}{$R$} & \multirow{2}{*}{$\begin{array}{r}\text { RMSE } \\
\left(\mu \mathrm{g} \mathrm{m}^{-3}\right)\end{array}$} & \multirow{2}{*}{$\begin{array}{r}\text { MFB } \\
\left.(\mu \mathrm{g} \mathrm{m})^{-3}\right)\end{array}$} & \multirow[t]{2}{*}{$|\mathrm{MFB}|$} & \multirow[t]{2}{*}{ MFE } \\
\hline & & & Obs. & Mod. & & & & & \\
\hline \multirow[t]{6}{*}{$\mathrm{PM}_{10}$} & NEU-We & 378 & 16.05 & 16.70 & 0.40 & 12.54 & $1.24 \%$ & $18.20 \%$ & $49.41 \%$ \\
\hline & NEU-Ce & 280 & 17.84 & 15.83 & 0.38 & 13.32 & $9.73 \%$ & $18.70 \%$ & $53.11 \%$ \\
\hline & MED-We & 171 & 23.31 & 20.23 & 0.47 & 31.46 & $-23.76 \%$ & $29.64 \%$ & $59.88 \%$ \\
\hline & MED-Ce & 7 & 29.09 & 22.47 & 0.30 & 20.90 & $-23.45 \%$ & $26.11 \%$ & $55.15 \%$ \\
\hline & MED-Ea & 93 & 54.43 & 21.99 & 0.19 & 54.41 & $-73.18 \%$ & $80.20 \%$ & $89.44 \%$ \\
\hline & ALL & 929 & 21.86 & 17.59 & 0.38 & 18.34 & $-14.14 \%$ & $26.87 \%$ & $56.41 \%$ \\
\hline \multirow[t]{5}{*}{$\mathrm{PM}_{2.5}$} & NEU-We & 155 & 9.38 & 11.84 & 0.51 & 7.78 & $22.97 \%$ & $34.47 \%$ & $54.82 \%$ \\
\hline & NEU-Ce & 95 & 11.64 & 11.75 & 0.40 & 8.48 & $12.10 \%$ & $21.61 \%$ & $53.40 \%$ \\
\hline & MED-We & 66 & 11.12 & 9.83 & 0.48 & 8.71 & $-6.81 \%$ & $35.09 \%$ & $58.18 \%$ \\
\hline & MED-Ce & 1 & 24.68 & 22.69 & 0.57 & 10.22 & $-28.09 \%$ & $28.09 \%$ & $53.29 \%$ \\
\hline & ALL & 317 & 10.46 & 11.40 & 0.47 & 8.14 & $13.55 \%$ & $30.99 \%$ & $55.05 \%$ \\
\hline
\end{tabular}

genic emissions. Contributions are 0.04 and $0.02 \%$ of SOA and nitrates, respectively, from fire sources.

\section{Evaluation of model results}

This section presents the results of the reference simulation (all emissions included), evaluated against the observations presented in Sect. 2, to quantify the model performance for aerosol modeling.

\subsection{Comparison with in situ PM surface concentrations}

Surface PM simulation is evaluated using the correlation, the mean fractional error (MFE) and the mean fractional bias (MFB) between observations and collocated modeled surface concentrations:

$\mathrm{MFB}=\frac{1}{N} \sum_{i=1}^{N} \frac{\left(C_{\mathrm{mod}}-C_{\mathrm{obs}}\right)}{\left(C_{\mathrm{mod}}+C_{\mathrm{obs}}\right) / 2}$

$\mathrm{MFE}=\frac{1}{N} \sum_{i=1}^{N} \frac{\left|C_{\mathrm{mod}}-C_{\mathrm{obs}}\right|}{\left(C_{\mathrm{mod}}+C_{\mathrm{obs}}\right) / 2}$

These statistical indicators are widely used in PM performance evaluation studies. Proposed by Boylan and Russell (2006) for PM, both the MFE and MFB must be lower than or equal to 50 and $\pm 30 \%$, respectively, to achieve the performance goals (level of accuracy considered to be close to the best a model can be expected to achieve), and must be lower than or equal to 75 and $\pm 60 \%$ to meet the performance criteria (level of accuracy acceptable for standard modeling applications). The MFB and MFE are computed at each station, and averaged. Additionally, the absolute MFB for each station is averaged, and the correlation coefficient $(R)$ and the root mean square error (RMSE) are computed:

$\mathrm{RMSE}=\sqrt{\frac{\sum_{i=1}^{N}\left(C_{\mathrm{mod}}-C_{\mathrm{obs}}\right)^{2}}{N}}$

Tables 2 and 3 summarize the hourly and daily statistical results averaged over the regions NEU-We (378 stations for $\mathrm{PM}_{10}$ and 155 for $\mathrm{PM}_{2.5}$ ), NEU-Ce (280 and 95), MED-We (171 and 66), and MED-Ea (93 stations for $\left.\mathrm{PM}_{10}\right)$. MED-Ce do not contain enough AirBase stations to allow statistically significant comparison (7 for $\mathrm{PM}_{10}$ and 1 for $\mathrm{PM}_{2.5}$ ). For the time period and the entire domain of this study, the MFE and MFB on daily mean values are 46.25 and $29.28 \%$, respectively, for $\mathrm{PM}_{10}$, and 43.74 and $31.18 \%$ for $\mathrm{PM}_{2.5}$. CHIMERE $\mathrm{PM}_{10}$ daily mean values thus meet the performance goal and $\mathrm{PM}_{2.5}$ the performance criteria defined above. For hourly comparisons, the performance goal is not met on average over the region $\left(\mathrm{MFE}=56.41 \%\right.$ and $\mathrm{MFB}=26.87 \%$ for $\mathrm{PM}_{10}$, $\mathrm{MFE}=55.05 \%$ and $\mathrm{MFB}=30.99 \%$ for $\mathrm{PM}_{2.5}$ ), but the model performance criteria are met. Indeed, the performance criteria are met for more than $90 \%$ of all the stations, and the performance goal is met for more than $40 \%$ of them.

In the regional comparisons, the highest differences are obtained in the MED-Ea region (26.9\% of the stations meet the performance criteria and only $3.2 \%$ the performance goal for $\left.\mathrm{PM}_{10}\right)$. A strong underestimation is noticed in this region with a MFB $=-73.18 \%$.

In the MED-We region, $82.5 \%$ of the stations meet the performance criteria and $25.7 \%$ the performance goal for $\mathrm{PM}_{10}$. Peak concentrations are often overestimated by the model for both $\mathrm{PM}_{10}$ and $\mathrm{PM}_{2.5}$, whereas levels are underestimated otherwise $(\mathrm{MF}=-23.8$ and $-6.8 \%$, respectively, for $\mathrm{PM}_{10}$ and $\mathrm{PM}_{2.5}$ ).

The MFB is relatively good for other regions (in general under $20 \%$ except for NEU-We), indicating that PM concentrations do not have an excessive bias. The correlation coef- 
Table 3. Performance statistics for the simulation of daily PM with CHIMERE (Mod.) compared to coincident station measurements (Obs.) during the summer of 2012.

\begin{tabular}{|c|c|c|c|c|c|c|c|c|c|}
\hline \multirow[t]{2}{*}{ Variable } & \multirow[t]{2}{*}{ Region } & \multirow{2}{*}{$\begin{array}{r}\text { Number } \\
\text { of stations }\end{array}$} & \multicolumn{2}{|c|}{ Mean $\left(\mu \mathrm{g} \mathrm{m}^{-3}\right)$} & \multirow[t]{2}{*}{$R$} & \multirow{2}{*}{$\begin{array}{r}\text { RMSE } \\
\left(\mu \mathrm{g} \mathrm{m}^{-3}\right)\end{array}$} & \multirow{2}{*}{$\begin{array}{r}\text { MFB } \\
\left(\mu \mathrm{g} \mathrm{m}^{-3}\right)\end{array}$} & \multirow[t]{2}{*}{$|\mathrm{MFB}|$} & \multirow[t]{2}{*}{ MFE } \\
\hline & & & Obs. & Mod. & & & & & \\
\hline \multirow{6}{*}{$\mathrm{PM}_{10}$} & NEU-We & 378 & 16.04 & 16.71 & 0.56 & 9.06 & $-1.15 \%$ & $17.60 \%$ & $36.31 \%$ \\
\hline & NEU-Ce & 280 & 17.84 & 15.85 & 0.54 & 9.82 & $-15.96 \%$ & $22.74 \%$ & $41.89 \%$ \\
\hline & MED-We & 171 & 23.27 & 20.24 & 0.62 & 15.92 & $-28.53 \%$ & $33.41 \%$ & $51.21 \%$ \\
\hline & MED-Ce & 7 & 29.36 & 22.45 & 0.46 & 15.77 & $-30.59 \%$ & $31.67 \%$ & $46.68 \%$ \\
\hline & MED-Ea & 93 & 54.75 & 22.04 & 0.39 & 44.55 & $-79.60 \%$ & $86.88 \%$ & $90.24 \%$ \\
\hline & ALL & 929 & 21.89 & 17.60 & 0.54 & 14.10 & $-18.73 \%$ & $29.28 \%$ & $46.25 \%$ \\
\hline \multirow[t]{5}{*}{$\mathrm{PM}_{2.5}$} & NEU-We & 155 & 9.3 & 11.80 & 0.65 & 5.8 & $22.27 \%$ & $33.57 \%$ & $44.39 \%$ \\
\hline & NEU-Ce & 95 & 11.61 & 11.75 & 0.55 & 5.81 & $4.71 \%$ & $22.47 \%$ & $39.10 \%$ \\
\hline & MED-We & 66 & 11.09 & 9.79 & 0.62 & 6.72 & $-12.09 \%$ & $37.21 \%$ & $48.59 \%$ \\
\hline & MED-Ce & 1 & 24.58 & 22.64 & 0.67 & 16.03 & $-26.95 \%$ & $26.95 \%$ & $50.21 \%$ \\
\hline & ALL & 317 & 10.43 & 11.37 & 0.61 & 6.01 & $9.70 \%$ & $31.18 \%$ & $43.74 \%$ \\
\hline
\end{tabular}
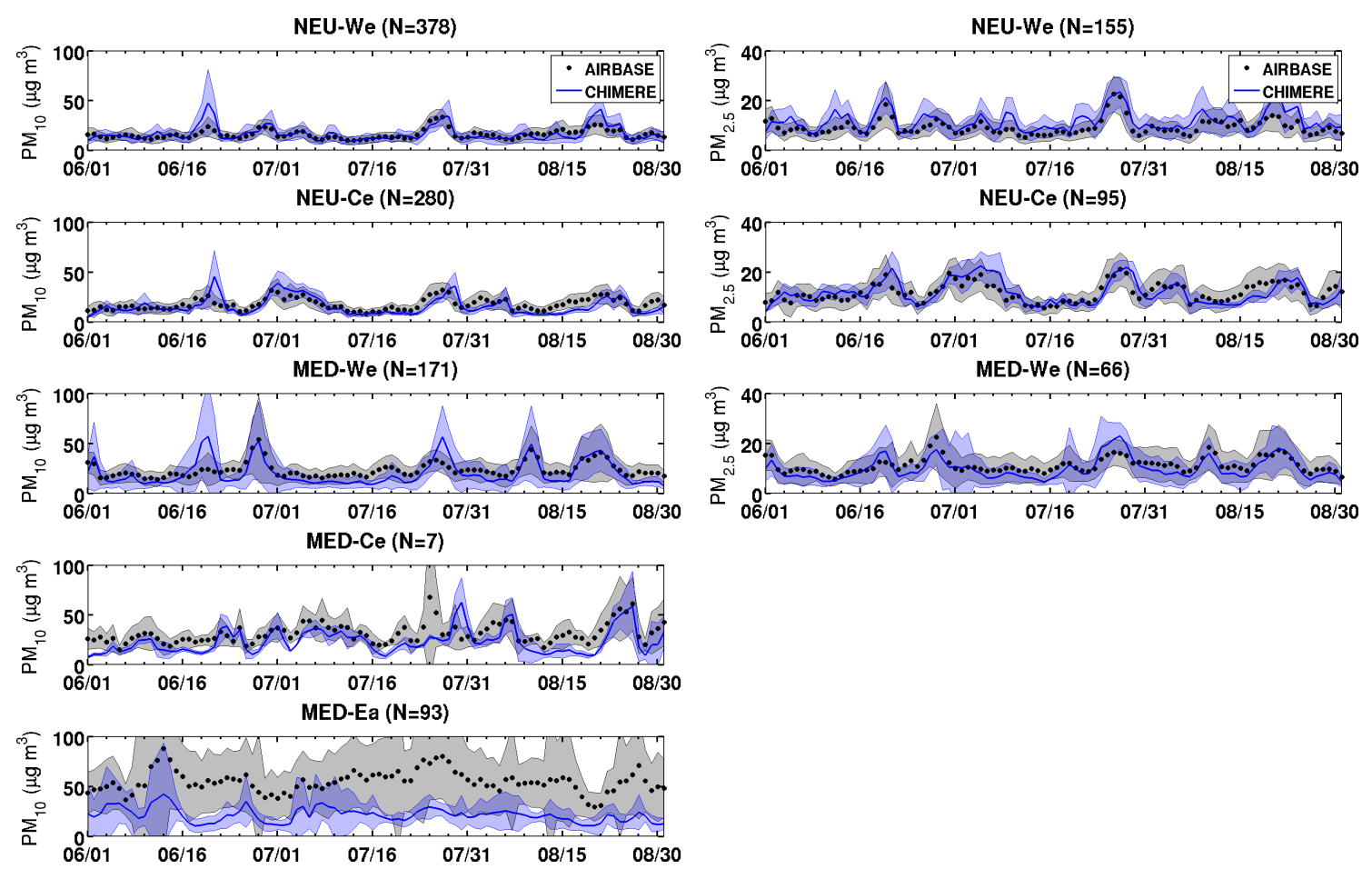

Figure 6. Temporal evolution during the summer of 2012 of observed daily mean surface $\mathrm{PM}_{10}$ (left column) and surface PM 2.5 (right column) concentrations at AirBase and the two ChArMEx rural stations in Corsica (number in each region indicated by the value of $N$ ), in addition to corresponding and collocated simulated daily mean surface concentration from CHIMERE (blue line). The corresponding standard deviation is indicated by a shaded area.

ficient is lower in the NEU-Ce region than in other regions except MED-Ea ( 0.38 for $\mathrm{PM}_{10}$ on 280 stations) for hourly comparisons, but not for daily averages with a correlation coefficient of 0.54. This suggests an influence of local sources for which the diurnal profiles used for the simulations may not be appropriate for the region.

Figure 6 shows the temporal evolution of surface PM, averaged daily over the NEU-We, NEU-Ce and MED-We sub- regions, as well as MED-Ce and MED-Ea for $\mathrm{PM}_{10}$. The levels of surface PM are consistent between observations and model, and the different peaks are well captured, especially in the northern part of the domain. In the Mediterranean basin, model levels are underestimated between 4 and 24 July, when no peak is detected either by observations or by the model. Peaks of pollution during the end of July and August are slightly overestimated. For $\mathrm{PM}_{10}$, in MED- 
We, NEU-We and NEU-Ce, a peak is overestimated by the model on 20 June by a factor of up to $4\left(80 \mu \mathrm{g} \mathrm{m}^{-3}\right.$ instead of $20 \mu \mathrm{g} \mathrm{m}^{-3}$ in MED-We). High values are also observed for this date at some of the Mediterranean stations such as Miramas (Fig. 3) but not at other stations where the model overestimates strongly the peak value, particularly in the south of France. These peaks are attributed to a dust transport event as discussed in Sect. 5.1. However, there is no associated overestimation of AOD values by the model compared to the observations (MODIS or AERONET). This suggests that the overestimation in surface PM may be due to an overestimated transport at low altitudes, i.e., a wrong vertical distribution of the dust plumes. However, it may also be explained by an excess in total mass and a shift in the aerosol size distribution towards finer particles, as highlighted by Menut et al. (2015) through comparisons of CHIMERE simulations with AERONET retrievals of the size distribution. An excess in $\mathrm{PM}$ concentration would then result in a correct AOD due to the variation of the extinction efficiency with the size of the aerosol.

\subsection{Comparison with aerosol optical depth (AOD) measurements}

To evaluate modeled AOD, we compare it to two data sets: MODIS satellite data and AERONET data at specific stations. For each statistic, we collocate in time and space the simulated AOD with the corresponding data set.

Figure 7 illustrates the time series of observed AOD and corresponding simulated values for each sub-region, and Table 4 , the associated statistics. The modeled AOD is close to the observations in all regions except for NEU-We, with a correlation coefficient ranging from 0.56 (NEU-Ea) to 0.77 (MED-Ce) and a MFE of $34.3 \%$ for comparisons to AERONET and $27.6 \%$ for comparisons to MODIS. The simulated AOD is underestimated in the eastern and southern parts of the domain, with a MFB of $-10 \%$ in MED-Ea for AERONET, $-31.4 \%$ for MODIS. In MED-Ea, the evaluation with MODIS data is more robust as there is more information than AERONET data in this sub-region (Fig. 1). This underestimation is also seen in the time series of Fig. 7 and coherent with the underestimation of $\mathrm{PM}_{10}$ noticed in the previous section. The variability of observations is greater than in the model, and than in other regions. The fine fraction of AOD from MODIS (not shown) is low, indicating that the total AOD in this region is due to coarse particles. The model is thus missing some coarse particle sources in this area.

Highest values are seen in MED-We, and the model manages to reproduce these values at the right timing (highest correlation coefficient) even if it moderately underestimates them (MFB of $-27.4 \%$ with respect to MODIS). Particularly, the peak at the beginning of July is underestimated by CHIMERE. The region with the lowest error and bias is MED-Ce, where the frequency and the intensity of peaks are lower.
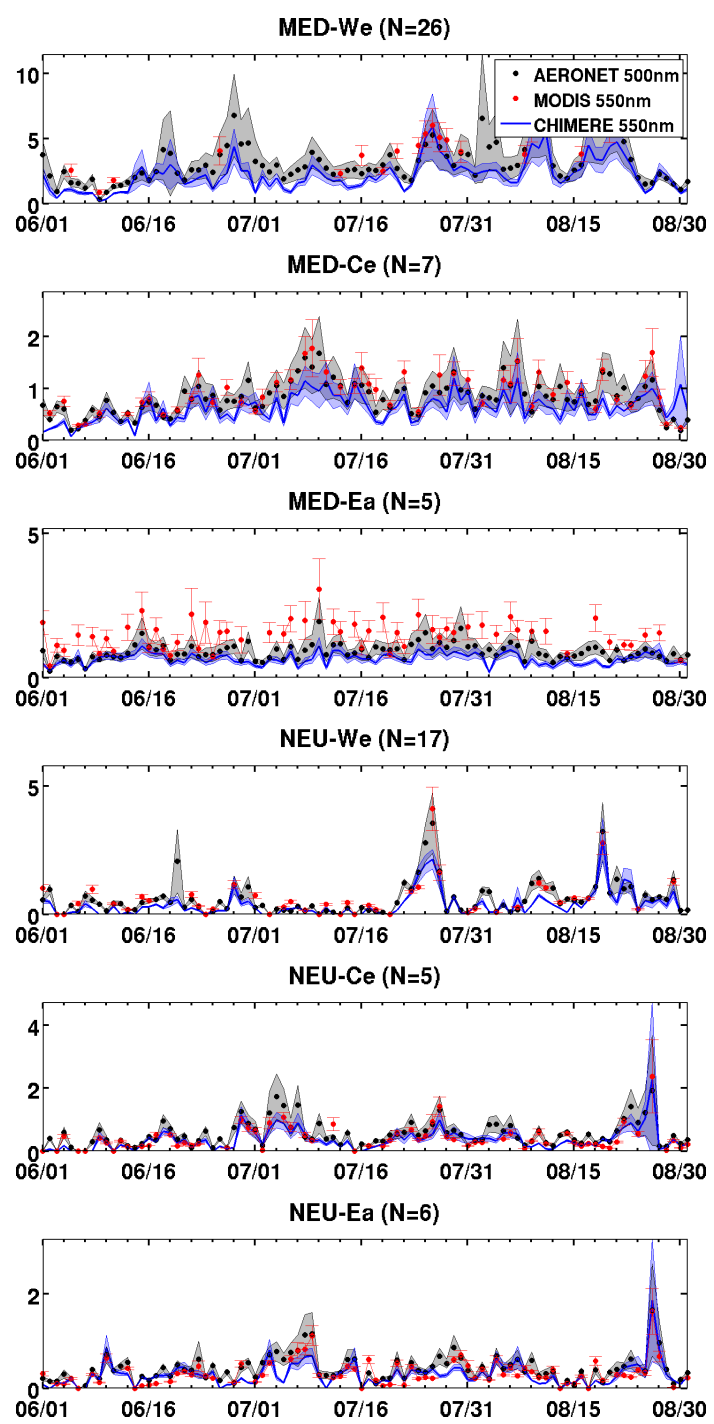

Figure 7. Temporal evolution of the daily mean AOD observed at $500 \mathrm{~nm}$ at the AERONET stations (black dots) and at $550 \mathrm{~nm}$ from MODIS Aerosol Products (red dots), in addition to simulated AOD at $550 \mathrm{~nm}$ by the CHIMERE model (blue line) during the summer of 2012. The standard deviation among the stations is indicated in grey and blue shaded area for AERONET and CHIMERE, respectively, and with red bars for MODIS. Number of stations in each region is indicated by the value of $N$.

\section{Regional sensitivity to emission sources}

In this section, the sensitivity of surface PM concentrations and total AOD to the different sources is analyzed based on the series of sensitivity simulations described in Sect. 3.4.

\subsection{Surface particulate matter}

Average relative contributions during the summer of 2012 to surface $\mathrm{PM}_{2.5}$ and $\mathrm{PM}_{10}$ over the domain are presented in Figs. 8 and 9. Table 5 summarizes the contributions from 
Table 4. Performance statistics of hourly AOD simulated by CHIMERE (Mod.) during the summer of 2012, compared to the coincidently observed AOD from AERONET at $500 \mathrm{~nm}$ and MODIS at $550 \mathrm{~nm}$ (Obs.).

\begin{tabular}{llrrrrrrrr}
\hline Variable & Region & $\begin{array}{r}\text { Number } \\
\text { of stations }\end{array}$ & $\begin{array}{c}\text { Number } \\
\text { of pairs }\end{array}$ & $\begin{array}{c}\text { Mean } \\
\text { Obs. }\end{array}$ & Mod. & $R$ & RMSE & MFB & MFE \\
\hline AOD AERONET (500 nm) & NEU-We & 17 & 748 & 0.15 & 0.15 & 0.49 & 0.10 & $-1.63 \%$ & $40.79 \%$ \\
& NEU-Ce & 5 & 326 & 0.22 & 0.19 & 0.71 & 0.10 & $-15.22 \%$ & $34.51 \%$ \\
& NEU-Ea & 6 & 245 & 0.19 & 0.17 & 0.72 & 0.07 & $-14.53 \%$ & $29.42 \%$ \\
& MED-We & 25 & 1729 & 0.20 & 0.17 & 0.77 & 0.09 & $-6.46 \%$ & $34.80 \%$ \\
& MED-Ce & 7 & 427 & 0.22 & 0.21 & 0.69 & 0.08 & $-1.59 \%$ & $27.84 \%$ \\
& MED-Ea & 5 & 448 & 0.21 & 0.18 & 0.71 & 0.07 & $-9.96 \%$ & $24.78 \%$ \\
& ALL & 65 & 3923 & 0.19 & 0.17 & 0.68 & 0.09 & $-6.36 \%$ & $34.33 \%$ \\
\hline AOD MODIS (550 nm) & NEU-We & & 225 & 0.19 & 0.13 & 0.37 & 0.08 & $-27.40 \%$ & $29.54 \%$ \\
& NEU-Ce & & 58 & 0.21 & 0.16 & 0.70 & 0.07 & $-15.08 \%$ & $22.40 \%$ \\
& NEU-Ea & & 184 & 0.18 & 0.16 & 0.56 & 0.06 & $-8.31 \%$ & $13.33 \%$ \\
& MED-We & & 537 & 0.30 & 0.22 & 0.74 & 0.10 & $-27.39 \%$ & $31.64 \%$ \\
& MED-Ce & & 449 & 0.22 & 0.19 & 0.74 & 0.04 & $-6.10 \%$ & $22.52 \%$ \\
& MED-Ea & & 327 & 0.25 & 0.16 & 0.67 & 0.10 & $-31.35 \%$ & $38.59 \%$ \\
& ALL & & 3380 & 0.24 & 0.18 & 0.63 & 0.06 & $-18.75 \%$ & $27.61 \%$ \\
\hline
\end{tabular}
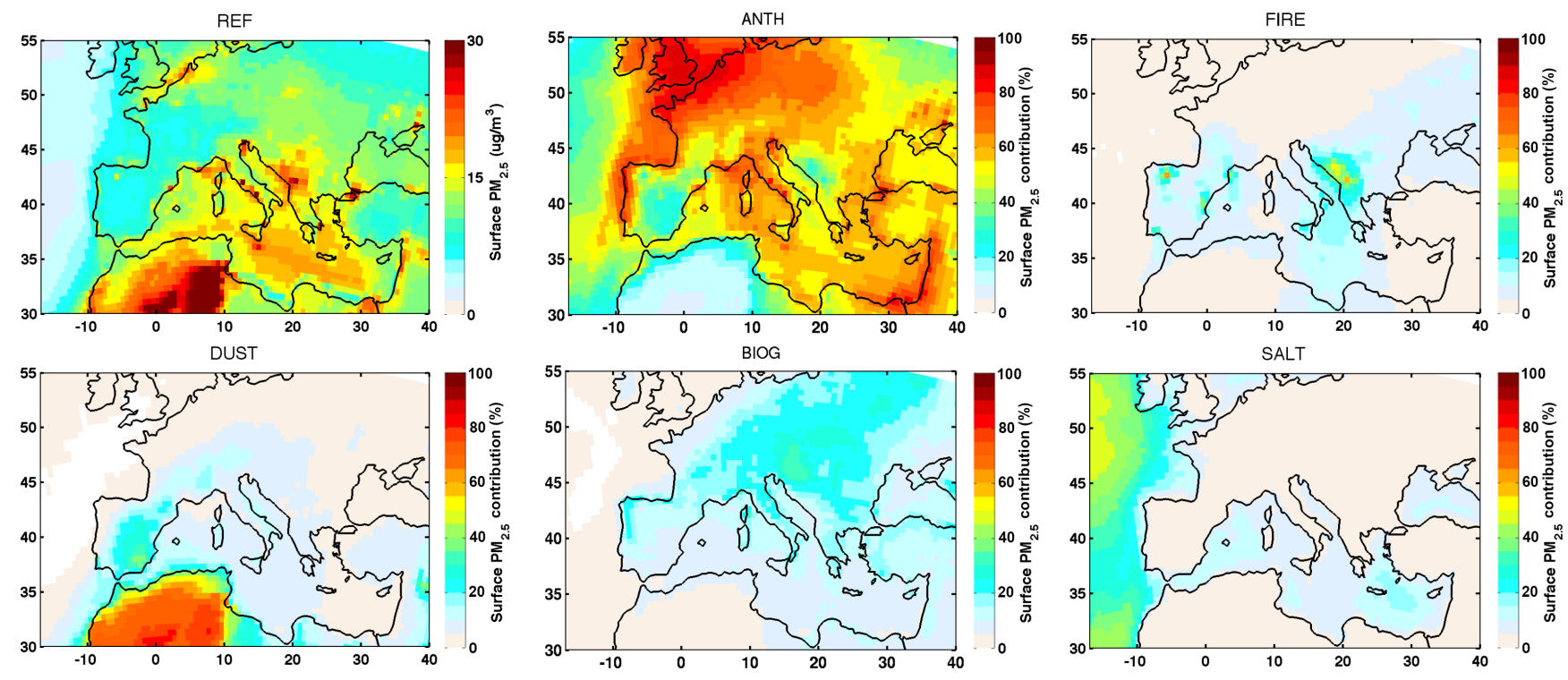

Figure 8. Relative contribution of each source type (i.e., the baseline simulation minus the sensitivity simulation where the respective source has been eliminated) to the simulated surface $\mathrm{PM}_{2.5}$, averaged over the period (1 June to 31 August 2012). The top left represents the reference surface concentration over the same period.

the different source types in each sub-region of Table 1 . As already highlighted in the general evaluation of the simulations, surface concentrations and total AOD are the largest over North Africa and the Mediterranean area, especially the western Mediterranean area.

Table 5 shows that concentrations of $\mathrm{PM}_{10}$ are about three time higher than those of $\mathrm{PM}_{2.5}$ (38.3 vs. $13 \mu \mathrm{g} \mathrm{m}^{-3}$ on average over the total period and domains). Surface $\mathrm{PM}_{10}$ also presents a stronger spatial variability (concentrations of surface $\mathrm{PM}_{10}$ ranges on average from $13.2 \mu \mathrm{g} \mathrm{m}^{-3}$ in NEU-Ea to $88.2 \mu \mathrm{g} \mathrm{m}^{-3}$ in MED-We, whereas concentrations of surface
$\mathrm{PM}_{2.5}$ ranges from $9.5 \mu \mathrm{g} \mathrm{m}^{-3}$ in NEU-We to $15.7 \mu \mathrm{g} \mathrm{m}^{-3}$ in MED-Ce).

The two most important contributors in the domain are anthropogenic and mineral dust emissions, which account, on average, respectively, for 52 and $17 \%$ of surface $\mathrm{PM}_{2.5}$, and 19 and $62 \%$ of surface $\mathrm{PM}_{10}$. Anthropogenic emissions clearly dominate both surface $\mathrm{PM}_{2.5}$ and $\mathrm{PM}_{10}$ in the northern part of the domain (up to 90 and $75 \%$ on average) but are also the main contribution to surface $\mathrm{PM}_{2.5}$ above the Mediterranean basin $(\sim 50 \%)$ and most particularly, as expected, around populated coastal areas. 

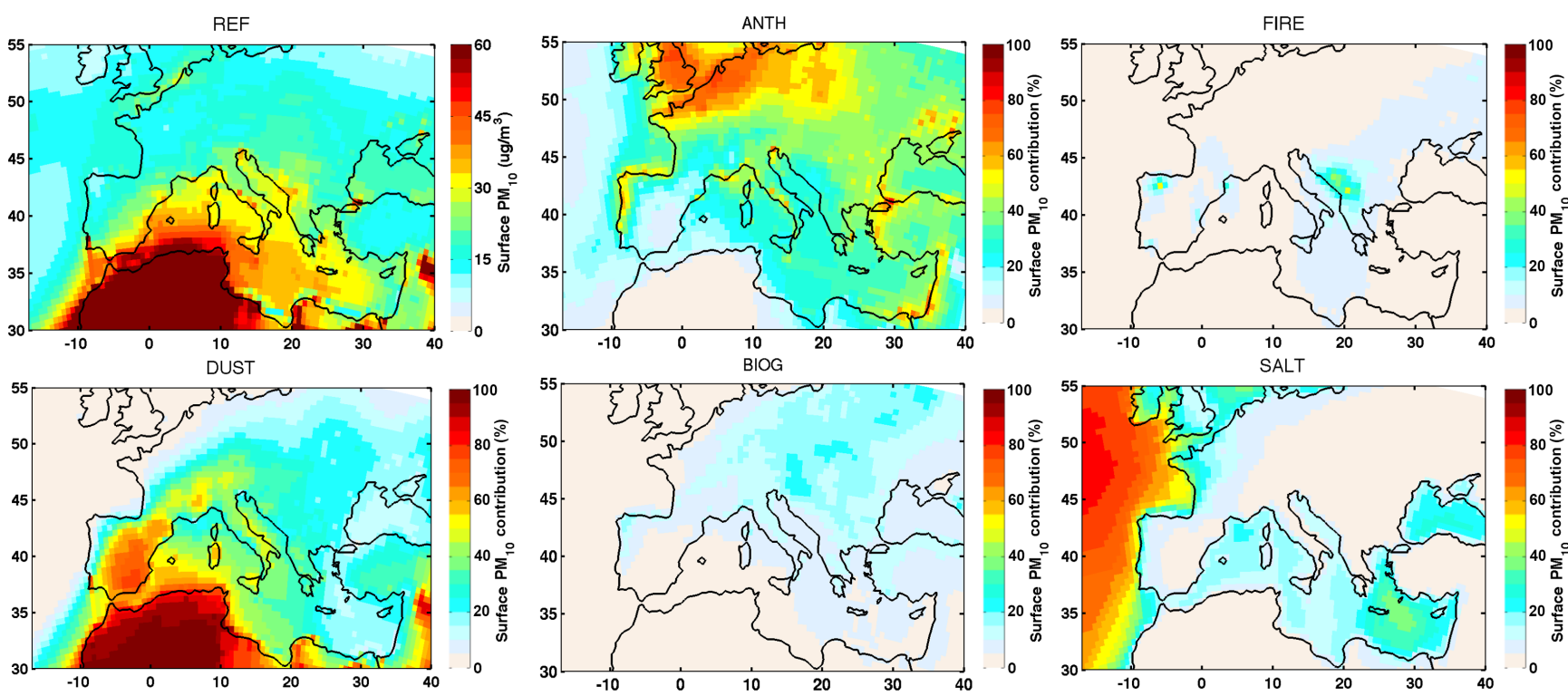

Figure 9. Relative contribution of each source type (i.e., the baseline simulation minus the sensitivity simulation where the respective source has been eliminated) to the simulated surface $\mathrm{PM}_{10}$, averaged over the period (1 June to 31 August 2012). The top left represents the reference surface concentration over the same period.

Since the main dust emissions are located in North Africa, dust dominate the aerosol budget in this region. They also represent the main contribution to surface $\mathrm{PM}_{10}$ concentrations in the western Mediterranean area (Spain, south of France and Italy). The average contribution of mineral dust in the MED-We region is estimated to $86 \%$ for surface $\mathrm{PM}_{10}$ and $44 \%$ for $\mathrm{PM}_{2.5}$. In this region, the mean concentration of surface $\mathrm{PM}_{10}$ over the period is exceeding the Euro-

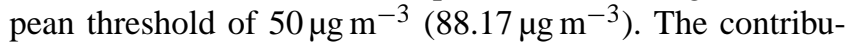
tion of mineral dust alone in this region exceeds this threshold $\left(75.63 \mu \mathrm{g} \mathrm{m}^{-3}\right)$. Long-range transport also results in significant contributions in northern Europe $(22 \%$ of surface $\mathrm{PM}_{10}$ on average in region NEU-Ce).

Fire emissions are more sporadic and thus represent a lower contribution to the average surface concentrations. However, significant increase during the summer of 2012 is obtained in Spain and the Balkans, close to the main fire events (Fig. 5). The maps show an impact reaching up to $20 \%$ locally on average during the summer (Figs. 8 and 9). The largest regional contribution is obtained for the MED-Ce region, with $12 \%$ of $\mathrm{PM}_{2.5}$ associated with fires.

As expected, sea salt emissions are the main contribution to PM above the Atlantic Ocean. However, their relative contribution above continents is low, except in the coastal areas and over northwestern Europe, where it reaches $29 \%$ of surface $\mathrm{PM}_{10}$. Over coastal cities, the impact of sea salts at the surface can be as large as that of anthropogenic emissions.

Biogenic emissions have an important contribution to PM in central Europe, where they are mainly located (Fig. 5). They account for almost $20 \%$ of surface $\mathrm{PM}_{2.5}$ in the NEUCe region.
Figure 11 shows the temporal evolution of surface $\mathrm{PM}_{2.5}$ and $\mathrm{PM}_{10}$, and their associated source contributions, integrated over the different sub-regions depicted in Table 1: NEU-We, NEU-Ce and NEU-Ea, MED-We, MED-Ce and MED-Ea. It shows that the daily variability above the chosen regions is large, especially for surface $\mathrm{PM}_{10}$, with diverse contributions. The variability in the northern part of the domain is mainly controlled by anthropogenic emissions. However, surface $\mathrm{PM}_{10}$ concentrations in the NEU-We region are also frequently affected by mineral dust (20-21 June, 1 July, end of August) and by sea salts. In the NEU-Ce and NEUEa regions, most of the high peaks in $\mathrm{PM}_{10}$ are attributed to mineral dust transport events.

Extreme concentrations are simulated in the western and central Mediterranean areas (MED-We and Ce), here again mainly due to large contributions from mineral dust emissions. These impact mainly surface $\mathrm{PM}_{10}$, while $\mathrm{PM}_{2.5}$ are often dominated by a more constant contribution from anthropogenic emissions. Fires are another significant contribution in these regions at the end of July and August for surface $\mathrm{PM}_{2.5}$.

Comparisons to surface observations highlighted an overestimate of the largest $\mathrm{PM}_{10}$ peaks in the simulations in the NEU-We, NEU-Ce and MED-We regions (Fig. 11). This suggests that mineral dust transport at low altitudes is too large in the model.

\subsection{Vertical distributions and AOD}

Figure 12 presents the vertical distributions of PM in the simulations, averaged over each of the sub-regions. As al- 
Table 5. Contributions of each emission source type to surface $\mathrm{PM}_{2.5}$ and $\mathrm{PM}_{10}$ concentrations and AOD for the full domain and the different sub-regions indicated in Table 1 over the period (1 June to 31 August 2012).

\begin{tabular}{|c|c|c|c|c|c|c|c|}
\hline \multirow[t]{2}{*}{ Region } & \multirow[t]{2}{*}{ Source } & \multicolumn{2}{|c|}{ Surface $\mathrm{PM}_{2.5}$} & \multicolumn{2}{|c|}{ Surface $\mathrm{PM}_{10}$} & \multicolumn{2}{|c|}{ AOD } \\
\hline & & $\mu \mathrm{g} \mathrm{m}^{-3}$ & $\%$ & $\mu \mathrm{g} \mathrm{m}^{-3}$ & $\%$ & ad. & $\%$ \\
\hline \multirow[t]{6}{*}{ All domain } & All sources & 13.00 & & 38.28 & & 0.19 & \\
\hline & Anthropogenic & 6.76 & $52.01 \%$ & 7.10 & $18.56 \%$ & 0.07 & $33.95 \%$ \\
\hline & Fires & 0.82 & $6.27 \%$ & 0.92 & $2.39 \%$ & 0.01 & $5.46 \%$ \\
\hline & Dust & 2.17 & $16.67 \%$ & 23.87 & $62.35 \%$ & 0.05 & $23.26 \%$ \\
\hline & Biogenic & 1.41 & $10.83 \%$ & 1.43 & $3.75 \%$ & 0.03 & $14.04 \%$ \\
\hline & Sea salt & 0.59 & $4.53 \%$ & 2.73 & $7.12 \%$ & 0.0012 & $0.59 \%$ \\
\hline \multirow[t]{6}{*}{ NEU-We } & All sources & 9.46 & & 15.10 & & 0.18 & \\
\hline & Anthropogenic & 7.11 & $75.13 \%$ & 7.44 & $49.28 \%$ & 0.10 & $54.87 \%$ \\
\hline & Fires & 0.12 & $1.22 \%$ & 0.13 & $0.86 \%$ & 0.00 & $2.20 \%$ \\
\hline & Dust & 0.15 & $1.62 \%$ & 1.18 & $7.84 \%$ & 0.01 & $4.83 \%$ \\
\hline & Biogenic & 0.68 & $7.24 \%$ & 0.69 & $4.57 \%$ & 0.01 & $5.01 \%$ \\
\hline & Sea salt & 0.68 & $7.19 \%$ & 4.33 & $28.70 \%$ & 0.00 & $1.14 \%$ \\
\hline \multirow[t]{6}{*}{ NEU-Ce } & All sources & 11.36 & & 15.86 & & 0.20 & \\
\hline & Anthropogenic & 7.16 & $62.98 \%$ & 7.56 & $47.67 \%$ & 0.09 & $42.65 \%$ \\
\hline & Fires & 0.42 & $3.66 \%$ & 0.45 & $2.82 \%$ & 0.01 & $4.62 \%$ \\
\hline & Dust & 0.52 & $4.58 \%$ & 3.45 & $21.78 \%$ & 0.02 & $9.97 \%$ \\
\hline & Biogenic & 2.48 & $21.83 \%$ & 2.51 & $15.82 \%$ & 0.04 & $21.51 \%$ \\
\hline & Sea salt & 0.16 & $1.42 \%$ & 0.58 & $3.68 \%$ & 0.00 & $0.43 \%$ \\
\hline \multirow{6}{*}{ NEU-Ea } & All sources & 9.78 & & 13.24 & & 0.19 & \\
\hline & Anthropogenic & 4.91 & $50.14 \%$ & 5.30 & $40.00 \%$ & 0.06 & $33.99 \%$ \\
\hline & Fires & 0.72 & $7.31 \%$ & 0.75 & $5.64 \%$ & 0.01 & $7.26 \%$ \\
\hline & Dust & 0.35 & $3.57 \%$ & 2.28 & $17.19 \%$ & 0.02 & $7.95 \%$ \\
\hline & Biogenic & 1.51 & $15.45 \%$ & 1.53 & $11.57 \%$ & 0.04 & $22.01 \%$ \\
\hline & Sea salt & 0.12 & $1.27 \%$ & 0.43 & $3.27 \%$ & 0.00 & $0.26 \%$ \\
\hline \multirow[t]{6}{*}{ MED-We } & All sources & 15.15 & & 88.17 & & 0.23 & \\
\hline & Anthropogenic & 4.92 & $32.50 \%$ & 5.17 & $5.86 \%$ & 0.04 & $18.72 \%$ \\
\hline & Fires & 0.83 & $5.45 \%$ & 0.95 & $1.08 \%$ & 0.01 & $4.51 \%$ \\
\hline & Dust & 6.54 & $43.19 \%$ & 75.63 & $85.78 \%$ & 0.11 & $49.20 \%$ \\
\hline & Biogenic & 0.82 & $5.38 \%$ & 0.84 & $0.95 \%$ & 0.02 & $7.12 \%$ \\
\hline & Sea salt & 0.62 & $4.12 \%$ & 2.96 & $3.36 \%$ & 0.00 & $0.58 \%$ \\
\hline \multirow[t]{6}{*}{ MED-Ce } & All sources & 15.66 & & 33.22 & & 0.20 & \\
\hline & Anthropogenic & 8.54 & $54.55 \%$ & 8.89 & $26.77 \%$ & 0.06 & $31.50 \%$ \\
\hline & Fires & 1.91 & $12.22 \%$ & 2.16 & $6.51 \%$ & 0.02 & $9.82 \%$ \\
\hline & Dust & 1.36 & $8.66 \%$ & 14.39 & $43.31 \%$ & 0.04 & $22.64 \%$ \\
\hline & Biogenic & 1.84 & $11.77 \%$ & 1.90 & $5.70 \%$ & 0.03 & $16.75 \%$ \\
\hline & Sea salt & 0.90 & $5.75 \%$ & 3.60 & $10.83 \%$ & 0.00 & $0.57 \%$ \\
\hline \multirow[t]{6}{*}{ MED-Ea } & All sources & 12.90 & & 22.90 & & 0.17 & \\
\hline & Anthropogenic & 7.83 & $60.67 \%$ & 8.24 & $35.98 \%$ & 0.07 & $41.01 \%$ \\
\hline & Fires & 0.45 & $3.48 \%$ & 0.50 & $2.20 \%$ & 0.01 & $3.81 \%$ \\
\hline & Dust & 0.78 & $6.06 \%$ & 7.09 & $30.98 \%$ & 0.02 & $10.88 \%$ \\
\hline & Biogenic & 1.42 & $11.02 \%$ & 1.45 & $6.34 \%$ & 0.03 & $18.64 \%$ \\
\hline & Sea salt & 0.67 & $5.17 \%$ & 2.84 & $12.40 \%$ & 0.00 & $0.46 \%$ \\
\hline
\end{tabular}

ready highlighted in the discussion above, surface concentrations are strongly affected by anthropogenic emissions, except in the western and central Mediterranean basins, which are dominantly affected by mineral dust transport. The vertical structures of the simulated dust layers have been eval- uated in Vuolo et al. (2009) with CALIOP LIDAR profiles during June to September 2006 and January to March 2007. It has been shown that the model has a vertical overspread of $50 \%$ in summer compared to the observations, but fewer multilayer dust situations. However, in MED-We and MED- 

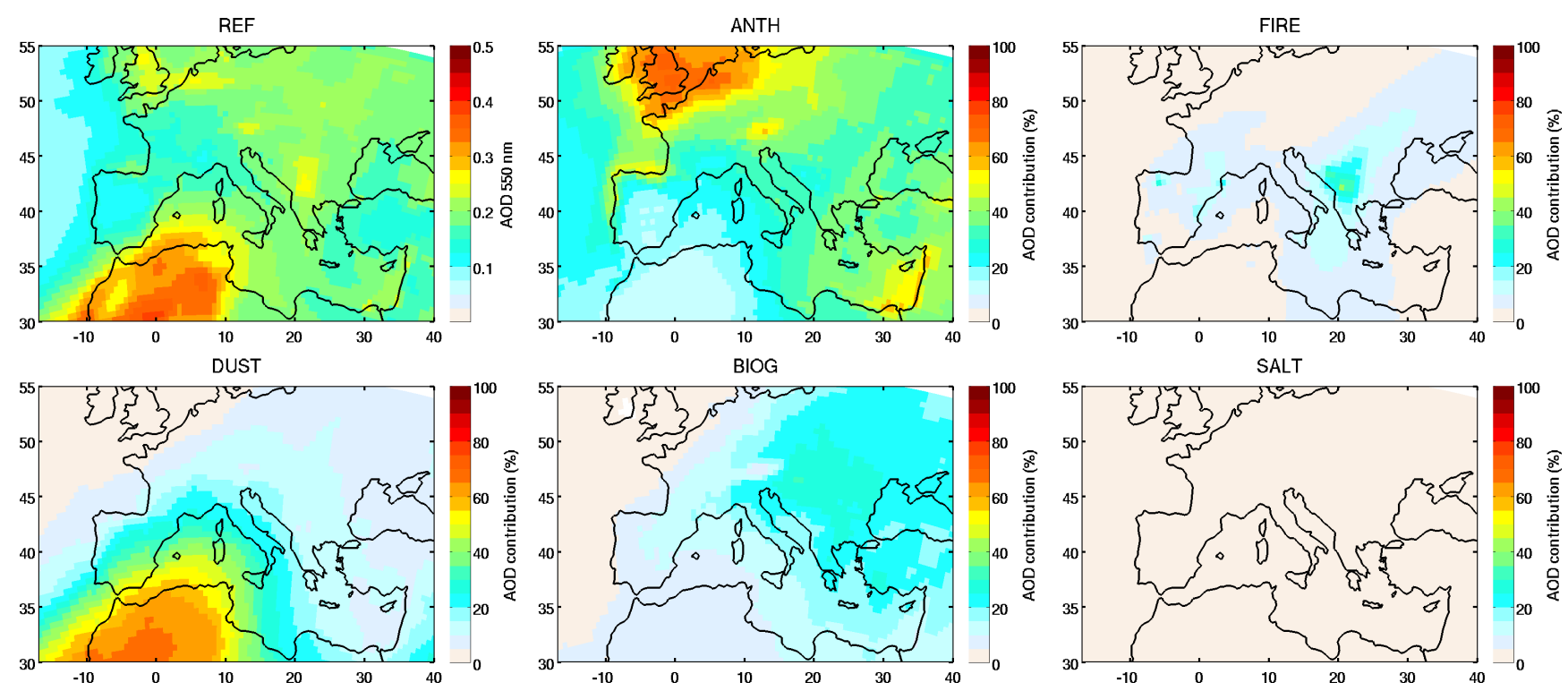

Figure 10. Relative contribution of each source type (i.e., the baseline simulation minus the sensitivity simulation where the respective source has been eliminated) to the simulated AOD at $550 \mathrm{~nm}$, averaged over the period (1 June to 31 August 2012). The top left represents the reference simulation of AOD over the same period.

$\mathrm{Ce}$, the vertical contribution from dust ranges from the surface to about $4-5 \mathrm{~km}$ (Fig. 12), which is a usual pattern compared to the climatology of Nabat et al. (2013). Dust affects mainly the free troposphere over the northern regions.

Fires and biogenic emissions are also important contributions, particularly for $\mathrm{PM}_{2.5}$. They often have maximum contributions in the lower troposphere. Sea salts contribute to $\mathrm{PM}_{10}$ in western Europe and the Mediterranean region, as well as in the central Mediterranean region, but are confined to the lower-most troposphere.

Contributions to the total AOD, which includes the signature of aerosols over the full vertical column, follow the same general patterns as the contributions to surface $\mathrm{PM}_{10}$ discussed above (average relative contributions in Fig. 10 and Table 5). However, the contribution of sea salts remains very low $(<1 \%)$.

Temporal variability over the selected sub-regions (Fig. 11, third column) shows that, similarly to what was obtained for surface PM, anthropogenic emissions control the variability in the NEU-We region, while mineral dust emissions are the main contribution in the MED-We region. The fire episodes of the end of August also contribute significantly to the total AOD in the NEU-Ea and MED-Ce regions. Compared to the total column (vertically integrated) concentrations of PM (not shown), source contributions to AOD follow contributions to $\mathrm{PM}_{2.5}$ concentrations. At the considered wavelength $(500 \mathrm{~nm})$, fine particles from anthropogenic or local fire emissions, even concentrated in the first layers, contribute more significantly (34\% for mean anthropogenic contribution) than larger mineral dust particles (23\%) at the considered wavelength $(500 \mathrm{~nm})$ to the calculated AOD.

\section{Contributions to air quality threshold exceedances}

The European Union has developed legislations to establish health-based standards for a number of atmospheric pollutants. For $\mathrm{PM}_{10}$, the air quality limit value is set, for healthbased considerations, to a daily mean of $50 \mu \mathrm{g} \mathrm{m}^{-3}$ and an annual mean of $40 \mu \mathrm{g} \mathrm{m}^{-3}$. For $\mathrm{PM}_{2.5}$, there is no regulation in Europe except for a quality aim of $25 \mu \mathrm{g} \mathrm{m}^{-3}$ in annual mean. In this section, the exceedances of the daily mean limit for $\mathrm{PM}_{10}$ concentrations are analyzed. We also analyze $\mathrm{PM}_{2.5}$ exceedances of a limit of $25 \mu \mathrm{g} \mathrm{m}^{-3}$ per $24 \mathrm{~h}$ (World Health Organisation recommendation, Krzyzanowski and Cohen, 2008). The number of stations in daily exceedances are calculated for both observations and colocated CHIMERE simulations. The simulations were undertaken at a regional scale, so that only exceedances at rural and background sites are considered.

\subsection{Raw estimates}

In total, $96.2 \%$ of the $\mathrm{PM}_{10}$ daily means are under the threshold of $50 \mu \mathrm{g} \mathrm{m}^{-3}$ in both observations and co-located simulation. The analysis will focus on the $3.8 \%$ other cases. Figure 13 presents the number of stations where the daily mean concentrations of $\mathrm{PM}_{10}$ and $\mathrm{PM}_{2.5}$ are above 50 and $25 \mu \mathrm{g} \mathrm{m}^{-3}$, respectively, in the observations or the model simulations within each sub-region (only the sub-regions where there are stations to compare with).

It clearly shows that the model detects more exceedances than the observations in MED-We, NEU-We and NEU-Ce (in total 1964 vs. 881 in the observations for $\mathrm{PM}_{10}$, positive bias of $42.5,86.6$ and $64.7 \%$, respectively), and some- 

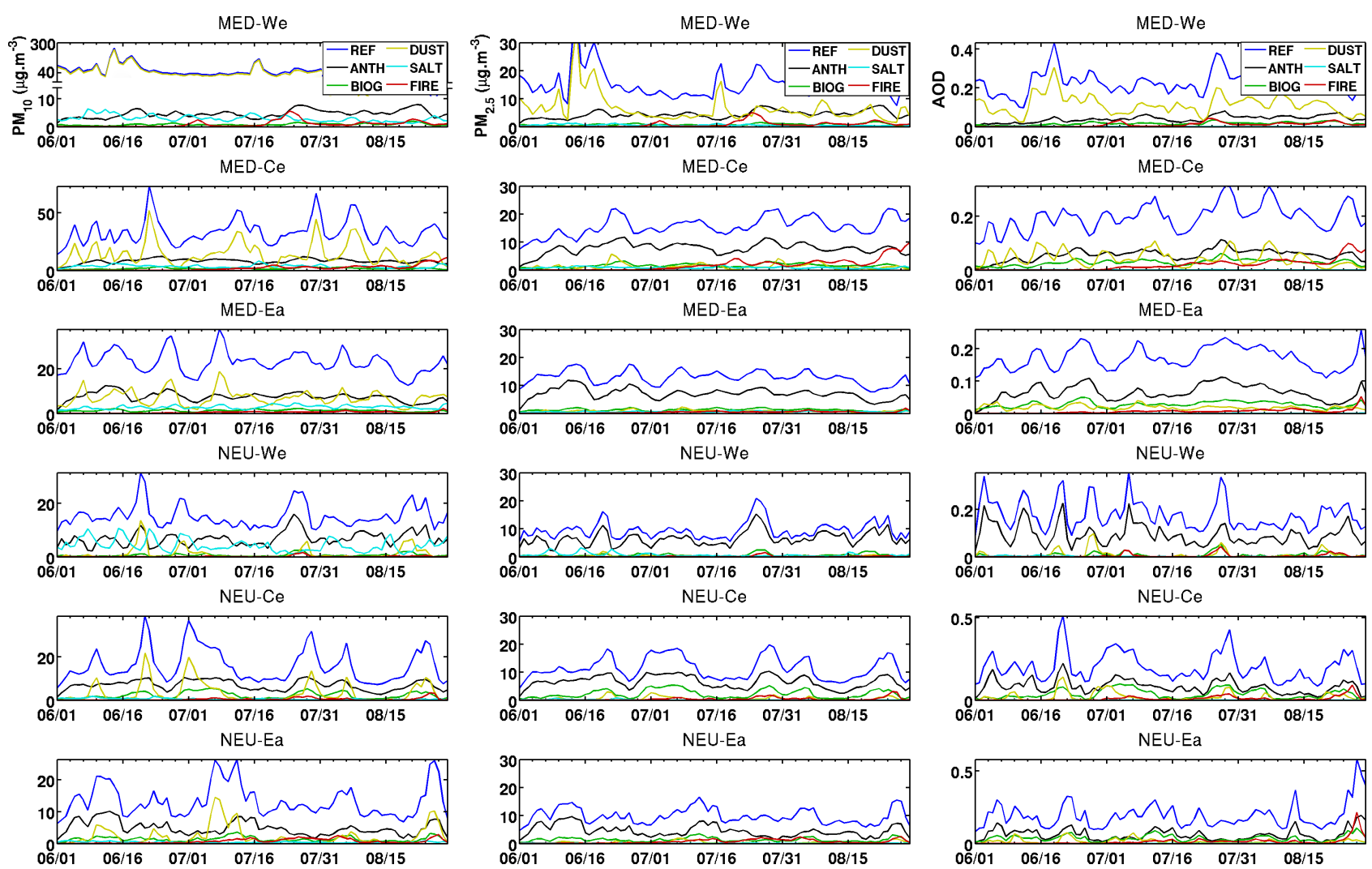

Figure 11. Temporal evolution during the summer of 2012 (1 June to 31 August 2012) of the total daily simulated surface PM 10 concentrations (left column), surface $\mathrm{PM}_{2.5}$ concentrations (central column), and AOD (right column), with the contributions from each source type (i.e., the baseline simulation minus the sensitivity simulation where the respective source has been eliminated), averaged within each sub-region indicated in Table 1.

times not at the same time (correlation coefficient of, respectively, 0.68, 0.42 and 0.43). In the MED-Ea region, several exceedances, particularly in the observations, are not reproduced in the model (MFB $=-73.18 \%$ ). The model only sees exceedances from anthropogenic emissions $(80 \%$ of the cases). The global underestimation of $\mathrm{PM}_{10}$ certainly due to missing coarse particle sources described in Sect. 4.2 does not allow the analysis of exceedances in this region.

For $\mathrm{PM}_{10}, 52.7 \%$ of the 881 observed exceedances are correctly captured by the model, the majority of them located in MED-We. More particularly, the event of 27-28 June is well simulated (Fig. 3) and is correctly detected in terms of number of stations in daily exceedances ( 29 exceedances for observations, 35 for the model, among the 92 stations). This is also the case for the two peaks in August (around 2030 exceedances). For $\mathrm{PM}_{2.5}$, only $23.5 \%$ of exceedances are correctly simulated, with the majority in NEU-We.

Figure 14 shows the contribution of each source when an exceedance is detected only by CHIMERE, and not in the observations. The peak of 20-21 June is present in the model simulations at almost every stations so that the number of simulated exceedances is a lot larger than in the observational data set. The model-only exceedances associated with this peak are attributed to mineral dust in the three regions (mixed with anthropogenic and biogenic contributions). The model also overestimates the number of stations in daily exceedances at the end of July (37 vs. 6 for observations in MED-We, 82 vs. 14 for NEU-We for $\mathrm{PM}_{10}$ ), with contributions from mineral dust, anthropogenic sources, and fires (stronger in MED-We and NEU-Ce).

Among the $464 \mathrm{PM}_{10}$ exceedances detected by both the model and the observations, $76.7 \%$ are due exclusively to dust (i.e., the dust source contributes to the $\mathrm{PM}_{10}$ surface concentration, when the exceedance is detected, for at least the value of the threshold, independently of the other sources), and $1.7 \%$ to fires. The other 100 exceedances are due to a mix contribution of dust (from $78.1 \%$ in MED-We to $85 \%$ in NEU-We), anthropogenic sources (about $15 \%$ in the three regions), biogenic sources (from $5.5 \%$ in MEDWe to $11.2 \%$ in NEU-Ce) and fires (from $1.7 \%$ in NEU-Ce to $10.2 \%$ in MED-We). For $\mathrm{PM}_{2.5}, 176$ on 1063 detections are coherent between the model and the observations, and 33.5 and $7.3 \%$ are due exclusively to anthropogenic and fires sources, respectively. The other 104 exceedances are due to a mix between anthropogenic sources (from $64.2 \%$ in MEDWe to $92.1 \%$ in NEU-We), biogenic sources (from $14.4 \%$ 

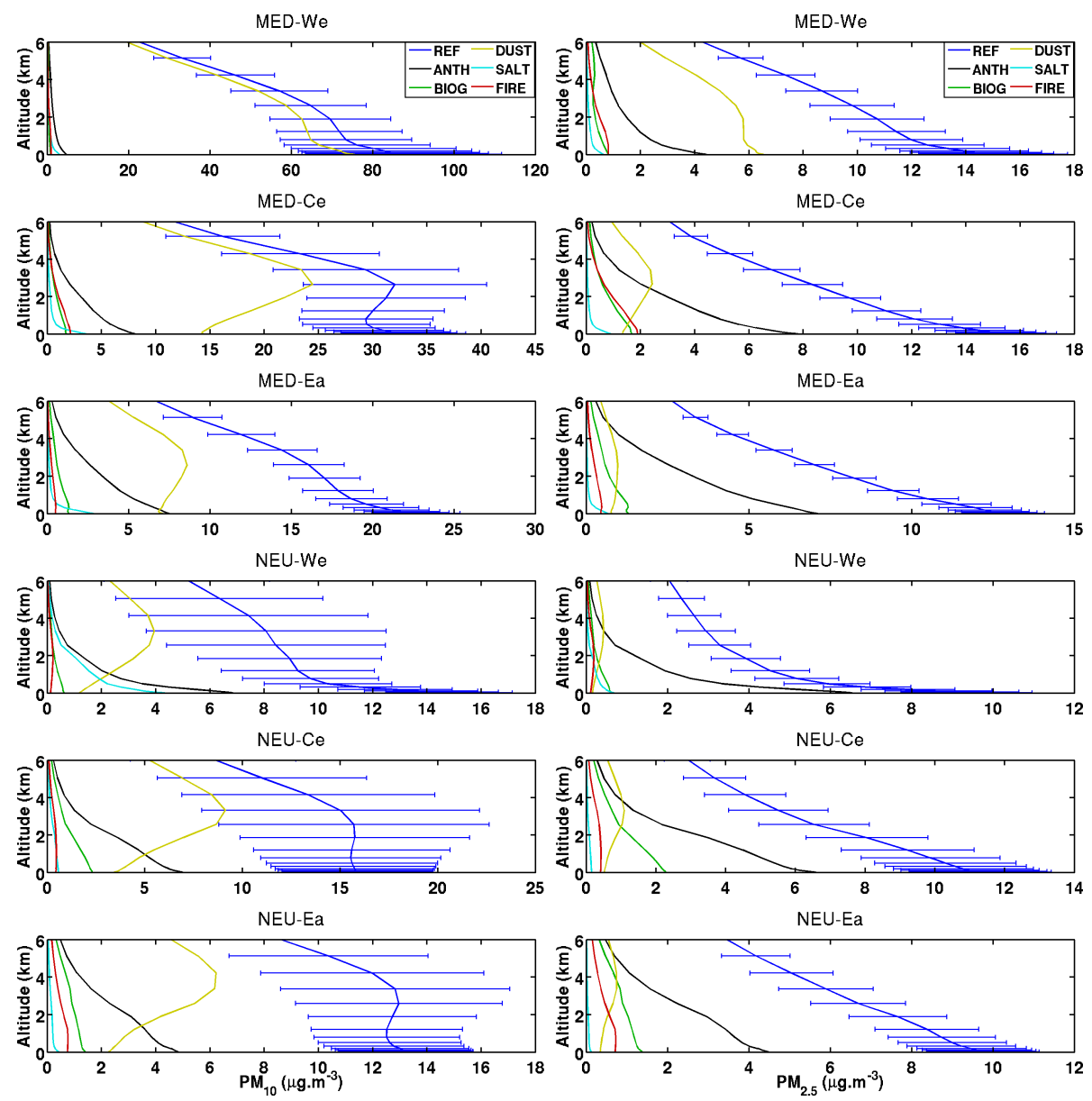

Figure 12. Mean vertical profiles of $\mathrm{PM}_{10}$ (left column) and $\mathrm{PM}_{2.5}$ (right column) for each sub-region indicated in Table 1 and for each source type. The standard deviation is represented only for the reference simulation by the horizontal bars.

in NEU-We to $39.3 \%$ in NEU-Ce), fires (from $1 \%$ in NEUWe to $15.6 \%$ in MED-We) and dust (1.7\% in NEU-We to $17.5 \%$ in MED-We).

\subsection{Optimized estimates}

These source contributions to daily exceedances might be uncertain due to the high overestimation of the model. An optimization is proposed to estimate more robust contributions of observed exceedances.

First, the bias on background levels is evaluated at each measurement station. The background is defined as the baseline concentration, on days when no significant peak is measured. It is generally associated with anthropogenic and biogenic sources, which have relatively low variability during the summer compared to dust and fire emissions.

The average "background bias" is estimated to $-6.3 \mu \mathrm{g} \mathrm{m}^{-3}$ for $\mathrm{PM}_{10}$ and $-1.9 \mu \mathrm{g} \mathrm{m}^{-3}$ for $\mathrm{PM}_{2.5}$ in MED-We, -0.93 and $1.3 \mu \mathrm{g} \mathrm{m}^{-3}$ in NEU-We, and -3.2 and $-0.2 \mu \mathrm{g} \mathrm{m}^{-3}$ in NEU-Ce, on average over all stations.
Then, for sporadic sources, i.e., for the dust and fires, the resulting bias at each point of a peak is subtracted only for contribution concentrations of the corresponding source. This processing is applied only when the model overestimates the concentrations with respect to observations, but not when a peak is detected only by the observations.

The corresponding new number of exceedances with this calculation is shown in Fig. 13 in a dashed blue line. The total number of exceedances is then 549 and 256, respectively, for $\mathrm{PM}_{10}$ and PM2.5 (instead of 1964 and 1063 initially) in total for the three regions, all of them detected also in the observations.

For these "optimized" concentrations, Fig. 15 shows the contribution of each source to the simulated exceedances. For the peaks at the end of June, the contribution of mineral dust to the exceedances is predominant particularly for $\mathrm{PM}_{10}$, mixed with anthropogenic pollution and fires from 28 June to 3 July (fires alone contribute to three exceedances at that time), as well as biogenic emissions from 18 to 23 August. In total, the only sources that result exclusively (i.e., when their contribution alone to PM concentration is more than the 

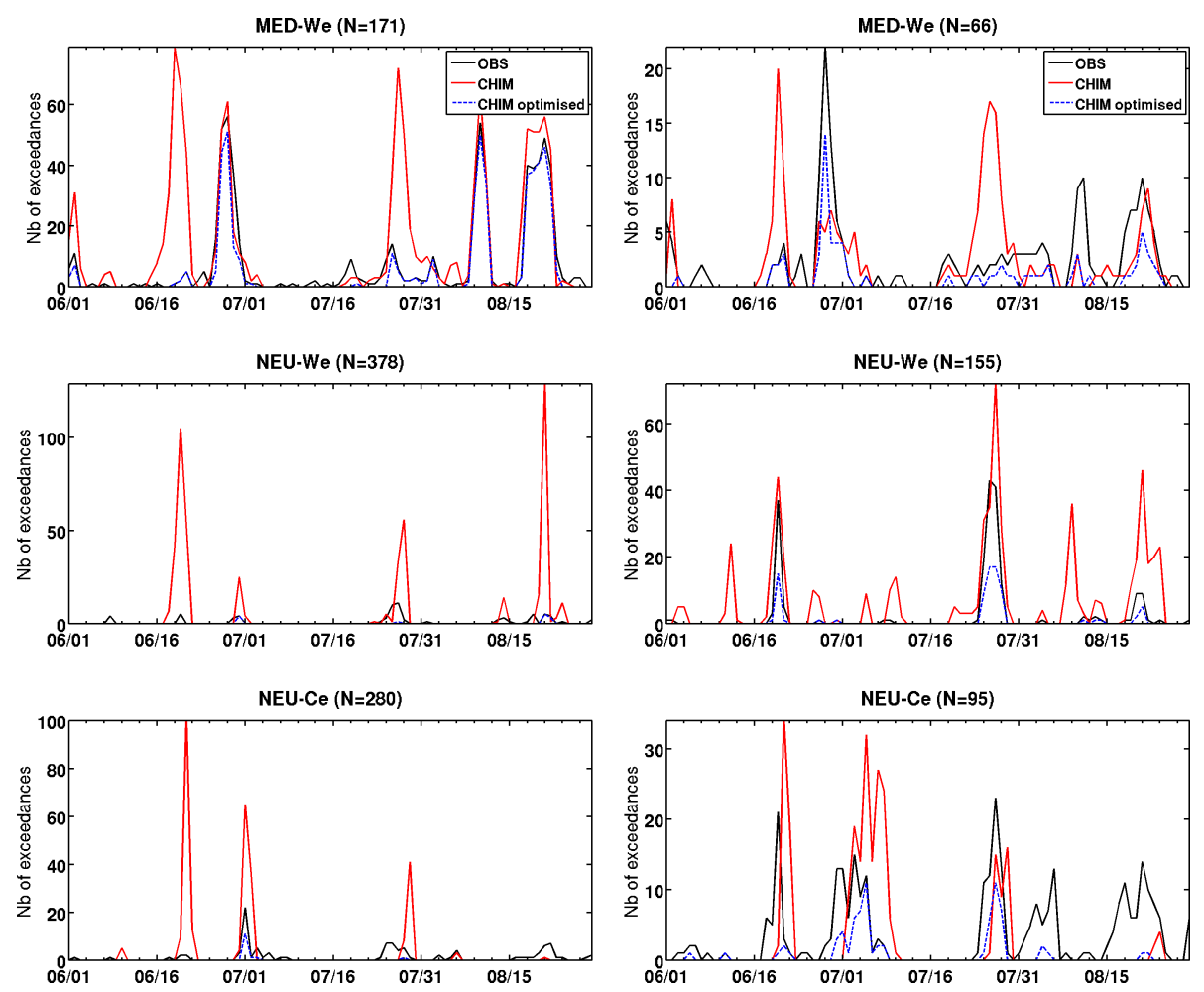

Figure 13. Number of stations in daily exceedances of the European Union air quality threshold of $50 \mu \mathrm{g} \mathrm{m}^{-3}$ for daily mean $\mathrm{PM}_{10}$ concentrations (left panel), and in daily exceedances of the WHO recommendation of $25 \mu \mathrm{g} \mathrm{m}^{-3}$ for PM 2.5 concentrations (right panel). This time series is computed during the summer of 2012 (1 June to 31 August 2012), as observed at the rural and background stations (black line) and simulated by the CHIMERE model at the same locations (red line). The dashed blue line is the number of exceedances when the bias is removed for each point, as described in Sect. 6.

threshold of $50 \mathrm{\mu g} \mathrm{m}^{-3}$ ) in an exceedance are dust (in $35.9 \%$ of the cases, i.e., 197 exceedances on the 549 observed and simulated) and fires (in $0.7 \%$ of the cases, i.e., 4 exceedances). The other 348 exceedances are due to a mixed contribution of several sources: anthropogenic sources contribute from $14.9 \%$ (NEU-We) to $24.2 \%$ (NEU-Ce) of the concentrations, biogenic from $4.1 \%$ (MED-We) to $15.7 \%$ (NEU-Ce), fires from $2.2 \%$ (NEU-Ce) to $7.2 \%$ (MED-We), and dust from $49.5 \%$ (MED-We) to $67 \%$ (NEU-We).

For $\mathrm{PM}_{2.5}$ exceedances, the only sources that result exclusively in concentrations above $25 \mathrm{\mu g} \mathrm{m}^{-3}$ are anthropogenic sources (54 exceedances on the 256 observed and simulated at the same time, i.e., $21.1 \%$ ) and fires (5 exceedances). The 197 other exceedances are a mix between anthropogenic sources (from $46.3 \%$ in MED-We to $80.6 \%$ in NEU-We), biogenic sources (12.6\% in MED-We to $30 \%$ in NEU-Ce), fires (1.6\% in NEU-We to $12.4 \%$ in MED-We) and mineral dust $(4.4 \%$ in NEU-We to $13.8 \%$ in MED-We). The WHO $25 \mu \mathrm{g} \mathrm{m}^{-3}$ limit recommendation is more often exceeded because of high anthropogenic contributions than natural sources.

Compared to the results without optimization, the main differences are for $\mathrm{PM}_{10}$, with fewer exceedances due exclusively to dust (197 vs. 356) and with a lower proportion to the $50 \mu \mathrm{g} \mathrm{m}^{-3}$ limit (49.5-67\% vs. $\left.78.1-85 \%\right)$. Contributions from the other sources (anthropogenic, biogenic, fires) are then lower than in the optimized results. This comparison means that the raw model simulation results are not robust enough to estimate contributions for an air quality purpose for $\mathrm{PM}_{10}$, but can be used as a valuable complement to observations to qualitatively attribute source types.

For $\mathrm{PM}_{2.5}$ however, the differences between the contributions deduced from the model only and from the model optimized with the observations are lower (for instance, 64.2$92.1 \%$ vs. $46.3-80.6 \%$ for anthropogenic contribution to the WHO $25 \mu \mathrm{g} \mathrm{m}^{-3}$ limit, $1.7-17.5 \%$ vs. $4.4-13.8 \%$ for mineral dust contribution), in coherence with the better performance of the model in the simulation of $\mathrm{PM}_{2.5}$ concentrations.

\section{Conclusions}

A sensitivity analysis was undertaken to estimate the contribution of anthropogenic, mineral dust, fire, biogenic and sea salt emissions on surface $\mathrm{PM}_{10}$, surface $\mathrm{PM}_{2.5}$ and total $\mathrm{AOD}$ during the summer of 2012 over Europe and the Mediterranean region. For this, simulations were performed using 

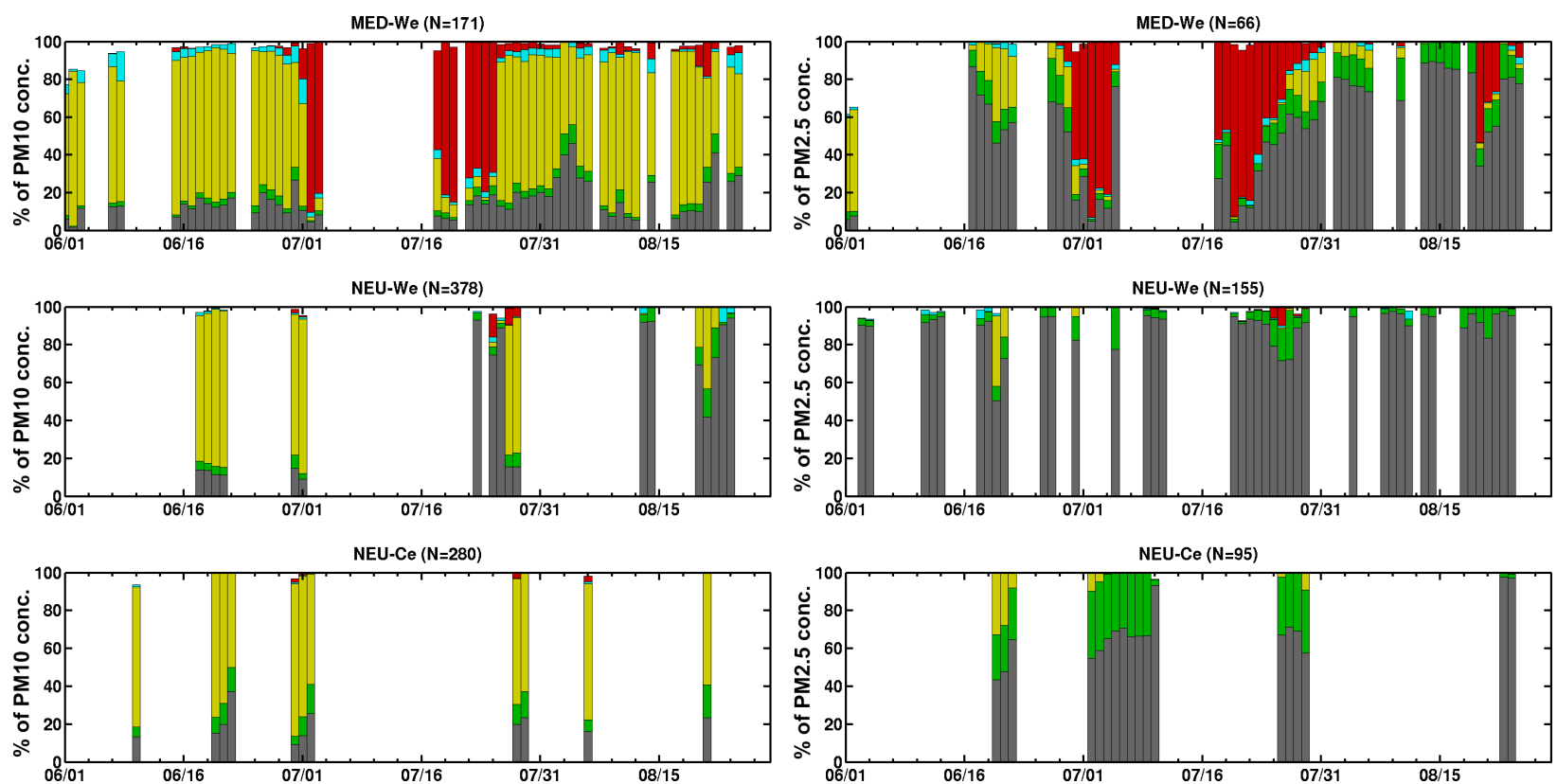

Figure 14. Simulated relative contribution of each source type to surface $\mathrm{PM}_{10}$ and $\mathrm{PM}_{2.5}$ concentrations during the summer of 2012 (1 June to 31 August 2012), on average when exceedances of the daily air quality threshold are detected only by the model at the stations ( $N$ is the number of stations in each region).
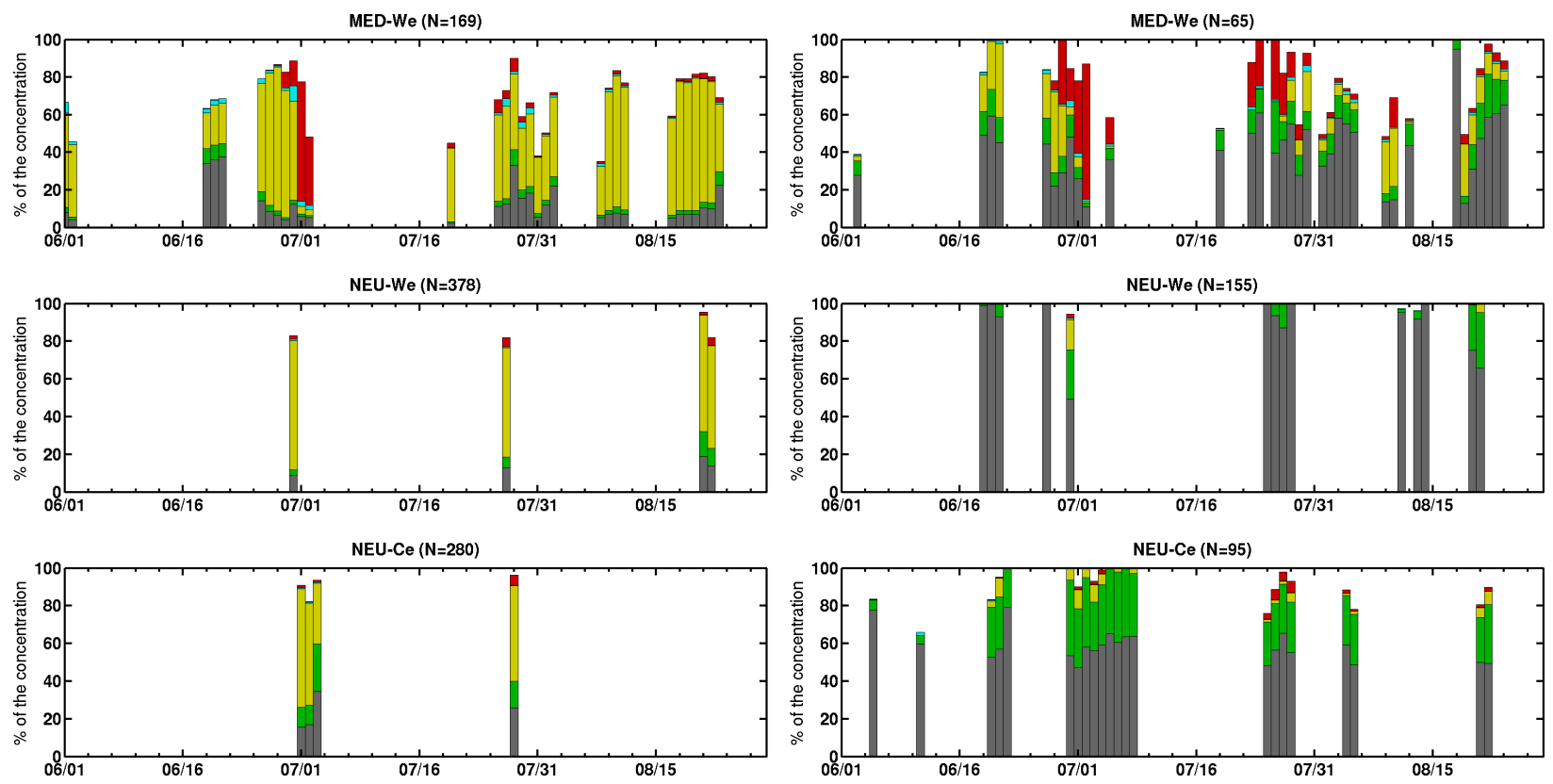

Figure 15. Same as Fig. 14 but when exceedances of the daily air quality threshold are detected by both observations and model after optimization of the background concentration baseline at the considered stations.

the CHIMERE regional CTM, including all sources (reference simulation) and removing one of these source at a time (sensitivity study).

The reference simulation has been evaluated against observations of surface PM from the AirBase network and two more stations in Corsica, and of AOD from the AERONET network and the MODIS space-based instrument. Although the density of the AirBase network is relatively high in parts of Europe, there are fewer observations around the Mediterranean basin, which makes the evaluation of surface PM concentration in those regions difficult. 
For the northern part of the domain and the western Mediterranean basin, the comparison between CHIMERE simulations and the observations of $\mathrm{PM}_{2.5}$ and $\mathrm{PM}_{10}$ surface concentrations has shown the ability of the model to simulate PM levels (the performance criteria are met for hourly values for more than $90 \%$ of the stations, i.e., both MFE and MFB are lower than or equal to 75 and $\pm 60 \%$, respectively). However, the associated variability is not well established with the correlation ranging from 0.19 to 0.57 depending on the region. All the main peaks are though reproduced by the model. The MFB is under $20 \%$ over the area, with some overestimations of peaks in the south west of the domain. The correlation is the lowest in the south east of the domain, associated with a strong underestimation of the observations, due to missing coarse particles sources, probably mineral dust. In the center north, statistics give slightly lower coherence with the observations, strongly influenced by local sources. This influence cannot be captured at the resolution used for the simulation $(50 \mathrm{~km})$. On the contrary, some peak values are overestimated in the northern part of the domain by a factor of up to 4 .

The comparison between simulated AOD and observations from AERONET and MODIS also shows good results with a correlation ranging from 0.37 to 0.77 , and a reasonable MFE (34.33\% with respect to AERONET and $27.61 \%$ with respect to MODIS). The underestimation is confirmed in the eastern and southern parts of the domain (MFB up to about $-31.4 \%)$.

Results of sensitivity simulations show that the EuroMediterranean domain is strongly influenced by mineral dust transport and anthropogenic emissions (62 and 19\%, respectively, for surface $\mathrm{PM}_{10}$ and 17 and $52 \%$ for surface $\mathrm{PM}_{2.5}$ ). For mineral dust, the contribution is particularly important in the western Mediterranean basin (86\% for surface $\mathrm{PM}_{10}$ and $44 \%$ for $\mathrm{PM}_{2.5}$ ) where the concentrations are the highest. In this region, all the extreme peaks are attributed to this source. In the northern part of the domain, mineral dust affects mainly the free troposphere. At the surface, anthropogenic emissions are dominant, particularly for surface $\mathrm{PM}_{2.5}$ (up to $75 \%$ ). However, surface peak concentrations attributed to mineral dust are observed. These peaks are generally strongly overestimated in the simulations. Fire emissions have also a significant contribution $(12.2 \%$ on average in MED-Ce) over the Mediterranean Sea, as well as sea salts on surface $\mathrm{PM}_{10}$ over coastal cities $(29 \%)$. Biogenic emissions impact central Europe mostly on $\mathrm{PM}_{2.5}(20 \%)$. Although levels of PM in MED-Ea are poorly reproduced in the model, the contribution of anthropogenic emissions to $\mathrm{PM}_{2.5}(60.7 \%$ on average) is coherent with Im and Kanakidou (2012).

Contributions to the total AOD show similar patterns, except for the contribution of sea salts, which is weaker. Contributions to the total AOD are closer to the contributions of simulated fine particles $\left(\mathrm{PM}_{2.5}\right.$ from anthropogenic and fire emissions) than coarse ones $\left(\mathrm{PM}_{10}\right)$ at the wavelength considered in this study $(550 \mathrm{~nm})$.

The same analysis was undertaken for the number of stations in daily exceedances of the European Union limit of $50 \mu \mathrm{g} \mathrm{m}^{-3}$ for $\mathrm{PM}_{10}$, and of the WHO recommendation of $25 \mu \mathrm{g} \mathrm{m}^{-3}$ for $\mathrm{PM}_{2.5}$ (over the stations considered in the study). The number of exceedances is overestimated by the model, mainly because of dust and fire contributions, but exceedances are captured at the right time. An optimized number of exceedances and associated contributions was computed to estimate more robust contributions to $\mathrm{PM}_{10}$ and $\mathrm{PM}_{2.5}$ concentration exceedances. Results show that for $\mathrm{PM}_{10}$, mineral dust and fires can be responsible exclusively of an exceedance (in $35.9 \%$ of the cases for mineral dust and $0.7 \%$ for fires), whereas it is anthropogenic sources $(21.1 \%)$ and fires $(0.02 \%)$ for $\mathrm{PM}_{2.5}$. The other exceedances are induced by a mixed contribution between mainly mineral dust (49.5-67\% for $\mathrm{PM}_{10}$ exceedance contributions, 4.4-13.8\% for $\mathrm{PM}_{2.5}$ ), anthropogenic sources (14.9-24.2\% and 46.3$80.6 \%$ ), biogenic sources $(4.1-15.7 \%$ and $12.6-30 \%)$ and fires (2.2-7.2\% and 1.6-12.4\%). Those results are estimated on average over the western part of Europe and the central north.

Acknowledgements. The authors acknowledge financial support from EIT - Climate-KIC as well as from the Centre National d'Etudes Spatiales (CNES) and DGA (in the framework of the APPAD project). The authors are grateful to the EEA for maintaining and providing the AirBase database for surface concentrations of several pollutants over Europe. We thank for the availability of the ChArMEx data Wani Tamas for the Venaco station and José Nicolas for the Ersa station. All investigators and staff who maintain and provide the AERONET data are also thanked. We finally wish to thank the National Aeronautics and Space Agency (NASA) for the availability of the MODIS data.

Edited by: F. Dulac

\section{References}

Alfaro, S. C. and Gomes, L.: Modeling mineral aerosol production by wind erosion: Emission intensities and aerosol size distributions in source areas, J. Geophys. Res.-Atmos., 106, 1807518084, doi:10.1029/2000JD900339, 2001.

Anttila, P., Stefanovska, A., Nestorovska-Krsteska, A., Grozdanovski, L., Atanasov, I., Golubov, N., Ristevski, P., Toceva, M., Lappi, S., and Walden, J.: Characterisation of extreme air pollution episodes in an urban valley in the Balkan Peninsula, Air Quality, Atmosphere \& Health, 1-13, doi:10.1007/s11869015-0326-7, 2015.

Barnaba, F., Angelini, F., Curci, G., and Gobbi, G. P.: An important fingerprint of wildfires on the European aerosol load, Atmos. Chem. Phys., 11, 10487-10501, doi:10.5194/acp-1110487-2011, 2011.

Bessagnet, B., Hodzic, A., Vautard, R., Beekmann, M., Cheinet, S., Honoré, C., Liousse, C., and Rouil, L.: 
Aerosol modeling with CHIMERE: preliminary evaluation at the continental scale, Atmos. Environ., 38, 2803-2817, doi:10.1016/j.atmosenv.2004.02.034, 2004.

Bian, H. and Prather, M.: Fast-J2: accurate simulation of stratospheric photolysis in global chemical models, J. Atmos. Chem., 41, 281-296, 2002.

Boldo, E., Medina, S., Le Tertre, A., Hurley, F., Mücke, H.-G., Ballester, F., and Aguilera, I.: Apheis: Health impact assessment of long-term exposure to $\mathrm{PM}_{2.5}$ in 23 European cities, Eur. J. Epidemiol., 21, 449-458, 2006.

Boselli, A., Caggiano, R., Cornacchia, C., Madonna, F., Mona, L., Macchiato, M., Pappalardo, G., and Trippetta, S.: Multi year sunphotometer measurements for aerosol characterization in a Central Mediterranean site, Atmos. Res., 104, 98-110, 2012.

Boylan, J. W. and Russell, A. G.: PM and light extinction model performance metrics, goals, and criteria for three-dimensional air quality models, Atmos. Environ., 40, 4946-4959, 2006.

Briant, R., Menut, L., Siour, G., and Prigent, C.: Homogeneized modeling of mineral dust emissions over Europe and Africa using the CHIMERE model, Geosci. Model Dev. Discuss., 7, 3441-3480, doi:10.5194/gmdd-7-3441-2014, 2014.

Burr, M. and Zhang, Y.: Source apportionment of fine particulate matter over the Eastern US Part II: source apportionment simulations using CAMX/PSAT and comparisons with CMAQ source sensitivity simulations., Atmos. Pollut. Res., 2, 318-336, doi:10.5094/APR.2011.037, 2011.

Carslaw, K. S., Boucher, O., Spracklen, D. V., Mann, G. W., Rae, J. G. L., Woodward, S., and Kulmala, M.: A review of natural aerosol interactions and feedbacks within the Earth system, Atmos. Chem. Phys., 10, 1701-1737, doi:10.5194/acp-10-17012010, 2010.

Chen, F. and Dudhia, J.: Coupling an advanced land surfacehydrology model with the Penn State-NCAR MM5 modeling system. Part I: Model implementation and sensitivity, Mon. Weather Rev., 129, 569-585, doi:10.1175/15200493(2001)129<0569:CAALSH>2.0.CO;2, 2001.

Curci, G., Palmer, P. I., Kurosu, T. P., Chance, K., and Visconti, G.: Estimating European volatile organic compound emissions using satellite observations of formaldehyde from the Ozone Monitoring Instrument, Atmos. Chem. Phys., 10, 11501-11517, doi:10.5194/acp-10-11501-2010, 2010.

Curci, G., Hogrefe, C., Bianconi, R., Im, U., Balzarini, A., Baró, R., Brunner, D., Forkel, R., Giordano, L., Hirtl, M., Honzak, L., Jiménez-Guerrero, P., Knote, C., Langer, M., Makar, P. A., Pirovano, G., Pérez, J. L., San José, R., Syrakov, D., Tuccella, P., Werhahn, J., Wolke, R., Žabkar, R., Zhang, J., and Galmarini, S.: Uncertainties of simulated aerosol optical properties induced by assumptions on aerosol physical and chemical properties: An AQMEII-2 perspective, Atmos. Environ., 115, 541552, doi:10.1016/j.atmosenv.2014.09.009, 2014.

Dall'Osto, M., Harrison, R. M., Highwood, E. J., O'Dowd, C., Ceburnis, D., Querol, X., and Achterberg, E. P.: Variation of the mixing state of Saharan dust particles with atmospheric transport, Atmos. Environ., 44, 3135-3146, 2010.

Daskalakis, N., Myriokefalitakis, S., and Kanakidou, M.: Sensitivity of tropospheric loads and lifetimes of short lived pollutants to fire emissions, Atmos. Chem. Phys., 15, 3543-3563, doi:10.5194/acp-15-3543-2015, 2015.
Dubovik, O., Smirnov, A., Holben, B., King, M., Kaufman, Y., Eck, T., and Slutsker, I.: Accuracy assessments of aerosol optical properties retrieved from Aerosol Robotic Network (AERONET) Sun and sky radiance measurements, J. Geophys. Res.-Atmos. (1984-2012), 105, 9791-9806, 2000.

Dudhia, J.: Numerical study of convection observed during the winter monsoon experiment using a mesoscale two-dimensional model, J. Atmos. Sci., 46, 3077-3107, 1989.

Fécan, F., Marticorena, B., and Bergametti, G.: Parametrization of the increase of the aeolian erosion threshold wind friction velocity due to soil moisture for arid and semi-arid areas, Ann. Geophys., 17, 149-157, doi:10.1007/s00585-999-0149-7, 1999.

Folberth, G. A., Hauglustaine, D. A., Lathière, J., and Brocheton, F.: Interactive chemistry in the Laboratoire de Météorologie Dynamique general circulation model: model description and impact analysis of biogenic hydrocarbons on tropospheric chemistry, Atmos. Chem. Phys., 6, 2273-2319, doi:10.5194/acp-62273-2006, 2006.

Gerasopoulos, E., Kouvarakis, G., Babasakalis, P., Vrekoussis, M., Putaud, J.-P., and Mihalopoulos, N.: Origin and variability of particulate matter $\left(\mathrm{PM}_{10}\right)$ mass concentrations over the Eastern Mediterranean, Atmos. Environ., 40, 4679-4690, 2006.

Gerasopoulos, E., Amiridis, V., Kazadzis, S., Kokkalis, P., Eleftheratos, K., Andreae, M. O., Andreae, T. W., El-Askary, H., and Zerefos, C. S.: Three-year ground based measurements of aerosol optical depth over the Eastern Mediterranean: the urban environment of Athens, Atmos. Chem. Phys., 11, 2145-2159, doi:10.5194/acp-11-2145-2011, 2011.

Ginoux, P., Chin, M., Tegen, I., Prospero, J. M., Holben, B., Dubovik, O., and Lin, S. J.: Sources and distributions of dust aerosols simulated with the GOCART model, J. Geophys. Res., 106, 20255-20273, 2001.

Gobbi, G., Barnaba, F., and Ammannat, L.: Estimating the impact of Saharan dust on the year $2001 \mathrm{PM}_{10}$ record of Rome, Italy, Atmos. Environ., 41, 261-275, 2007.

Gómez-Amo, J. L., Estellés, V., Segura, S., Marcos, C., Esteve, A. R., Pedrós, R., Utrillas, M. P., and Martínez-Lozano, J. A.: Analysis of a strong wildfire event over Valencia (Spain) during Summer 2012 - Part 1: Aerosol microphysics and optical properties, Atmos. Chem. Phys. Discuss., 13, 22639-22685, doi:10.5194/acpd-13-22639-2013, 2013.

Guenther, A., Karl, T., Harley, P., Wiedinmyer, C., Palmer, P. I., and Geron, C.: Estimates of global terrestrial isoprene emissions using MEGAN (Model of Emissions of Gases and Aerosols from Nature), Atmos. Chem. Phys., 6, 3181-3210, doi:10.5194/acp-63181-2006, 2006.

Hansen, J., Sato, M., and Ruedy, R.: Radiative forcing and climate response, J. Geophys. Res.-Atmos., 102, 6831-6864, doi:10.1029/96JD03436, 1997.

Hodzic, A., Madronich, S., Bohn, B., Massie, S., Menut, L., and Wiedinmyer, C.: Wildfire particulate matter in Europe during summer 2003: meso-scale modeling of smoke emissions, transport and radiative effects, Atmos. Chem. Phys., 7, 4043-4064, doi:10.5194/acp-7-4043-2007, 2007.

Holben, B., Eck, T., Slutsker, I., Tanré, D., Buis, J., Setzer, A., Vermote, E., Reagan, J., Kaufman, Y., Nakajima, T., Lavenu, F., Jankowiak, I., and Smirnov, A.: AERONET - A federated instrument network and data archive for aerosol characterization, Remote Sens. Environ., 66, 1-16, 1998. 
Hong, S.-Y. and Lim, J.-O. J.: The WRF single-moment 6-class microphysics scheme (WSM6), J. Korean Meteor. Soc, 42, 129$151,2006$.

Hong, S.-Y., Noh, Y., and Dudhia, J.: A new vertical diffusion package with an explicit treatment of entrainment processes, Mon. Weather Rev., 134, 2318-2341, doi:10.1175/MWR3199.1, 2006.

Iacono, M. J., Delamere, J. S., Mlawer, E. J., Shephard, M. W., Clough, S. A., and Collins, W. D.: Radiative forcing by longlived greenhouse gases: Calculations with the AER radiative transfer models, J. Geophys. Res.-Atmos. (1984-2012), 113, D13103, doi:10.1029/2008JD009944, 2008.

Im, U. and Kanakidou, M.: Impacts of East Mediterranean megacity emissions on air quality, Atmos. Chem. Phys., 12, 6335-6355, doi:10.5194/acp-12-6335-2012, 2012.

Im, U., Bianconi, R., Solazzo, E., Kioutsioukis, I., Badia, A., Balzarini, A., Baró, R., Bellasio, R., Brunner, D., Chemel, C., Curci, G., Denier van der Gon, H., Flemming, J., Forkel, R., Giordano, L., Jiménez-Guerrero, P., Hirtl, M., Hodzic, A., Honzak, L., Jorba, O., Knote, C., Makar, P., Manders-Groot, A., Neal, L., Pérez, J., Pirovano, G., Pouliot, G., San Jose, R., Savage, N., Schroder, W., Sokhi, R., Syrakov, D., Torian, A., Tuccella, P., Wang, K., Werhahn, J., Wolke, R., Zabkar, R., Zhang, Y., Zhang, J., Hogrefe, C., and Galmarini, S.: Evaluation of operational online-coupled regional air quality models over Europe and North America in the context of AQMEII phase 2. Part II: Particulate matter, Atmos. Environ., 115, 421-441, doi:10.1016/j.atmosenv.2014.08.072, 2015.

Israelevich, P., Ganor, E., Alpert, P., Kishcha, P., and Stupp, A.: Predominant transport paths of Saharan dust over the Mediterranean Sea to Europe, J. Geophys. Res.-Atmos., 117, D02205, doi:10.1029/2011JD016482, 2012.

Israelevich, P. L., Levin, Z., Joseph, J. H., and Ganor, E.: Desert aerosol transport in the Mediterranean region as inferred from the TOMS aerosol index, J. Geophys. Res.-Atmos., 107, AAC 13-1-AAC 13-13, doi:10.1029/2001JD002011, 2002.

Janjic, Z.: The surface layer in the NCEP Eta Model, Eleventh conference on numerical weather prediction, Norfolk, VA, 1923 August 1996, Amer. Meteor. Soc., Boston, MA, USA, 354$355,1996$.

Kain, J. S.: Convective parameterization for mesoscale models: The Kain-Fritsch scheme, The representation of cumulus convection in numerical models, Meteor. Monogr, 46, 165-170, 1993.

Kalnay, E., Kanamitsu, M., Kistler, R., Collins, W., Deaven, D., Gandin, L., Iredell, M., Saha, S., White, G., Woollen, J., Zhu, Y., Chelliah, M., Ebisuzaki, W., Higgins, W., Janowiak, J., Mo, K., Ropelewski, C., Wang, J., Leetmaa, A., Reynolds, R., Jenne, R., and Joseph, D.: The NCEP/NCAR 40-year reanalysis project, B. Am. Meteorol. Soc., 77, 437-471, 1996.

Kaskaoutis, D., Kambezidis, H., Nastos, P., and Kosmopoulos, P.: Study on an intense dust storm over Greece, Atmos. Environ., 42, 6884-6896, 2008.

Katsouyanni, K., Touloumi, G., Spix, C., Schwartz, J., Balducci, F., Medina, S., Rossi, G., Wojtyniak, B., Sunyer, J., Bacharova, L., Schouten, J. P., Ponka, A., and Anderson, H. R.: Short term effects of ambient sulphur dioxide and particulate matter on mortality in 12 European cities: results from time series data from the APHEA project, BMJ, 314, 1658, doi:10.1136/bmj.314.7095.1658, 1997.
Koçak, M., Mihalopoulos, N., and Kubilay, N.: Contributions of natural sources to high $\mathrm{PM}_{10}$ and $\mathrm{PM}_{2.5}$ events in the eastern Mediterranean, Atmos. Environ., 41, 3806-3818, 2007.

Koo, B., Dunker, A. M., and Yarwood, G.: Implementing the Decoupled Direct Method for Sensitivity Analysis in a Particulate Matter Air Quality Model, Environ. Sci. Technol., 41, 28472854, doi:10.1021/es0619962, 2007.

Koo, B., Wilson, G. M., Morris, R. E., Dunker, A. M., and Yarwood, G.: Comparison of source apportionment and sensitivity analysis in a particulate matter air quality model, Environ. Sci. Technol., 43, 6669-6675, doi:10.1021/es9008129, 2009.

Krzyzanowski, M. and Cohen, A.: Update of WHO air quality guidelines, Air Quality, Atmosphere \& Health, 1, 7-13, doi:10.1007/s11869-008-0008-9, 2008.

Lionello, P., Malanotte-Rizzoli, P., Boscolo, R., Alpert, P., Artale, V., Li, L., Luterbacher, J., May, W., Trigo, R., Tsimplis, M., Ulbrich, U., and Xoplaki, E.: The Mediterranean climate: an overview of the main characteristics and issues, Developments in Earth and Environmental Sciences, 4, 1-26, 2006.

Mailler, S., Menut, L., di Sarra, A. G., Becagli, S., Di Iorio, T., Formenti, P., Bessagnet, B., Briant, Régis, Luis GómezAmo, J., Mallet, M., Rea, Géraldine, Siour, G., Sferlazzo, D. M., Traversi, R., Udisti, R., and Turquety, S.: On the radiative impact of aerosols on photolysis rates: comparison of simulations and observations in the Lampedusa island during the ChArMEx/ADRIMED campaign, Atmos. Chem. Phys. Discuss., 15, 7585-7643, doi:10.5194/acpd-15-7585-2015, 2015.

Marticorena, B. and Bergametti, G.: Modeling the atmospheric dust cycle: 1 . Design of a soil-derived dust emission scheme, J. Geophys. Res.-Atmos., 100, 16415-16430, doi:10.1029/95JD00690, 1995.

Menut, L., Schmechtig, C., and Marticorena, B.: Sensitivity of the sandblasting fluxes calculations to the soil size distribution accuracy, J. Atmos. Ocean. Tech., 22, 1875-1884, doi:10.1175/JTECH1825.1, 2005.

Menut, L., Foret, G., and Bergametti, G.: Sensitivity of mineral dust concentrations to the model size distribution accuracy, J. Geophys. Res.-Atmos., 112, D10210, doi:10.1029/2006JD007766, 2007.

Menut, L., Chiapello, I., and Moulin, C.: Previsibility of mineral dust concentrations: The CHIMERE-DUST forecast during the first AMMA experiment dry season, J. Geophys. Res., 114, D07202, doi:10.1029/2008JD010523, 2009.

Menut, L., Goussebaile, A., Bessagnet, B., Khvorostiyanov, D., and Ung, A.: Impact of realistic hourly emissions profiles on air pollutants concentrations modelled with CHIMERE, Atmos. Environ., 49, 233-244, doi:10.1016/j.atmosenv.2011.11.057, 2012.

Menut, L., Bessagnet, B., Khvorostyanov, D., Beekmann, M., Blond, N., Colette, A., Coll, I., Curci, G., Foret, G., Hodzic, A., Mailler, S., Meleux, F., Monge, J.-L., Pison, I., Siour, G., Turquety, S., Valari, M., Vautard, R., and Vivanco, M. G.: CHIMERE 2013: a model for regional atmospheric composition modelling, Geosci. Model Dev., 6, 981-1028, doi:10.5194/gmd6-981-2013, 2013.

Menut, L., Mailler, S., Siour, G., Bessagnet, B., Turquety, S., Rea, G., Briant, R., Mallet, M., Sciare, J., Formenti, P., and Meleux, F.: Ozone and aerosol tropospheric concentrations variability analyzed using the ADRIMED measurements and the WRF 
and CHIMERE models, Atmos. Chem. Phys., 15, 6159-6182, doi:10.5194/acp-15-6159-2015, 2015.

Millán, M. M., José Sanz, M., Salvador, R., and Mantilla, E.: Atmospheric dynamics and ozone cycles related to nitrogen deposition in the western Mediterranean, Environ. Pollut., 118, 167-186, 2002.

Monahan, E. C.: In The Role of Air-Sea Exchange in Geochemical Cycling, chap. The ocean as a source of atmospheric particles, 129-163, Kluwer Academic Publishers, Dordrecht, the Netherlands, 1986.

Monks, P., Granier, C., Fuzzi, S., Stohl, A., Williams, M., Akimoto, H., Amann, M., Baklanov, A., Baltensperger, U., Bey, I., Blake, N., Blake, R., Carslaw, K., Cooper, O., Dentener, F., Fowler, D., Fragkou, E., Frost, G., Generoso, S., Ginoux, P., Grewe, V., Guenther, A., Hansson, H., Henne, S., Hjorth, J., Hofzumahaus, A., Huntrieser, H., Isaksen, I., Jenkin, M., Kaiser, J., Kanakidou, M., Klimont, Z., Kulmala, M., Laj, P., Lawrence, M., Lee, J., Liousse, C., Maione, M., McFiggans, G., Metzger, A., Mieville, A., Moussiopoulos, N., Orlando, J., O’Dowd, C., Palmer, P., Parrish, D., Petzold, A., Platt, U., Pöschl, U., Prévôt, A., Reeves, C., Reimann, S., Rudich, Y., Sellegri, K., Steinbrecher, R., Simpson, D., ten Brink, H., Theloke, J., van der Werf, G., Vautard, R., Vestreng, V., Vlachokostas, C., and von Glasow, R.: Atmospheric composition change - global and regional air quality, Atmos. Environ., 43, 5268-5350, doi:10.1016/j.atmosenv.2009.08.021, 2009.

Moulin, C., Lambert, C. E., Dayan, U., Masson, V., Ramonet, M., Bousquet, P., Legrand, M., Balkanski, Y. J., Guelle, W., Marticorena, B., Bergametti, G., and Dulac, F.: Satellite climatology of African dust transport in the Mediterranean atmosphere, J. Geophys. Res.-Atmos., 103, 13137-13144, doi:10.1029/98JD00171, 1998.

Nabat, P., Somot, S., Mallet, M., Chiapello, I., Morcrette, J. J., Solmon, F., Szopa, S., Dulac, F., Collins, W., Ghan, S., Horowitz, L. W., Lamarque, J. F., Lee, Y. H., Naik, V., Nagashima, T., Shindell, D., and Skeie, R.: A 4-D climatology (1979-2009) of the monthly tropospheric aerosol optical depth distribution over the Mediterranean region from a comparative evaluation and blending of remote sensing and model products, Atmos. Meas. Tech., 6, 1287-1314, doi:10.5194/amt-6-1287-2013, 2013.

Nabat, P., Somot, S., Mallet, M., Michou, M., Sevault, F., Driouech, F., Meloni, D., di Sarra, A., Di Biagio, C., Formenti, P., Sicard, M., Léon, J.-F., and Bouin, M.-N.: Dust aerosol radiative effects during summer 2012 simulated with a coupled regional aerosolatmosphere-ocean model over the Mediterranean, Atmos. Chem. Phys., 15, 3303-3326, doi:10.5194/acp-15-3303-2015, 2015.

Pace, G., Meloni, D., and di Sarra, A.: Forest fire aerosol over the Mediterranean basin during summer 2003, J. Geophys. Res.Atmos., 110, D21202, doi:10.1029/2005JD005986, 2005.

Péré, J., Mallet, M., Pont, V., and Bessagnet, B.: Evaluation of an aerosol optical scheme in the chemistrytransport model CHIMERE, Atmos. Environ.t, 44, 3688-3699, doi:10.1016/j.atmosenv.2010.06.034, 2010.

Pope III, C. A. and Dockery, D. W.: Health effects of fine particulate air pollution: lines that connect, JAPCA J. Air Waste Ma., 56, 709-742, 2006.

Prigent, C., Jiménez, C., and Catherinot, J.: Comparison of satellite microwave backscattering (ASCAT) and visible/near-infrared reflectances (PARASOL) for the estimation of aeolian aero- dynamic roughness length in arid and semi-arid regions, Atmos. Meas. Tech., 5, 2703-2712, doi:10.5194/amt-5-2703-2012, 2012.

Prospero, J. M., Ginoux, P., Torres, O., Nicholson, S. E., and Gill, T. E.: Environmental characterization of global sources of atmospheric soil dust identified with the Nimbus 7 Total Ozone Mapping Spectrometer (toms) absorbing aerosol product, Rev. Geophys., 40, 2-1-2-31, doi:10.1029/2000RG000095, 2002.

Putaud, J.-P., Van Dingenen, R., Alastuey, A., Bauer, H., Birmili, W., Cyrys, J., Flentje, H., Fuzzi, S., Gehrig, R., Hansson, H.C., Harrison, R. M., Herrmann, H., Hitzenberger, R., Hüglin, C., Jones, A. M., Kasper-Giebl, A., Kiss, G., Kousa, A., Kuhlbusch, T. A. J., Löschau, G., Maenhaut, W., Molnar, A., Moreno, T., Pekkanen, J., Perrino, C., Pitz, M., Puxbaum, H., Querol, X., Rodriguez, S., Salma, I., Schwarz, J., Smolik, J., Schneider, J., Spindler, G., ten Brink, H., Tursic, J., Viana, J., Wiedensohler, A. and Raes, F.: A European aerosol phenomenology-3: Physical and chemical characteristics of particulate matter from 60 rural, urban, and kerbside sites across Europe, Atmos. Environ., 44, 1308-1320, 2010.

Remer, L. A., Kaufman, Y. J., Tanré, D., Mattoo, S., Chu, D. A., Martins, J. V., Li, R.-R., Ichoku, C., Levy, R. C., Kleidman, R. G., Eck, T. F., Vermote, E., and Holben, B. N.: The MODIS Aerosol Algorithm, Products and Validation, Special Section, J. Atmos. Sci., 62, 947-973, 2005.

Remer, L. A., Tanre, D., Kaufman, Y. J., Levy, R., and Mattoo, S.: Algorithm for remote sensing of tropospheric aerosol from MODIS: Collection 005, National Aeronautics and Space Administration, available at: http://modis-atmos.gsfc.nasa.gov/ _docs/MOD04-MYD04_ATBD_C005.pdf (last access: 20 July 2015), 2006.

Ripoll, A., Minguillón, M. C., Pey, J., Pérez, N., Querol, X., and Alastuey, A.: Joint analysis of continental and regional background environments in the western Mediterranean: PM1 and PM10 concentrations and composition, Atmos. Chem. Phys., 15, 1129-1145, doi:10.5194/acp-15-1129-2015, 2015.

Rodriguez, S., Querol, X., Alastuey, A., and de la Rosa., J.: Atmospheric particulate matter and air quality in the Mediterranean: a review, Environ. Chem. Lett., 5, 1-7, doi:10.1007/s10311-0060071-0, 2007.

Roustan, Y., Sartelet, K., Tombette, M., Debry, É., and Sportisse, B.: Simulation of aerosols and gas-phase species over Europe with the POLYPHEMUS system. Part II: Model sensitivity analysis for 2001, Atmos. Environ., 44, 4219-4229, 2010.

Salvador, P., Alonso-Pérez, S., Pey, J., Artíñano, B., de Bustos, J. J., Alastuey, A., and Querol, X.: African dust outbreaks over the western Mediterranean Basin: 11-year characterization of atmospheric circulation patterns and dust source areas, Atmos. Chem. Phys., 14, 6759-6775, doi:10.5194/acp-14-6759-2014, 2014.

Sartelet, K. N., Couvidat, F., Seigneur, C., and Roustan, Y.: Impact of biogenic emissions on air quality over Europe and North America, Atmos. Environ., 53, 131-141, 2012.

Sayer, A. M., Hsu, N. C., Bettenhausen, C., and Jeong, M.-J.: Validation and uncertainty estimates for MODIS collection 6 "Deep Blue” aerosol data, J. Geophys. Res.-Atmos., 118, 7864-7872, 2013.

Skamarock, W., Klemp, J., Dudhia, J., Gill, D., Barker, D., Duda, M., Huang, X., Wang, W., and Powers, J.: A description of 
the advanced research WRF version 3., NCAR Technical Note, 123 pp., 2008.

Solazzo, E., Bianconi, R., Pirovano, G., Matthias, V., Vautard, R., Moran, M. D., Appel, K. W., Bessagnet, B., Brandt, J., Christensen, J. H., Chemel, C., Coll, I., Ferreira, J., Forkel, R., Francis, X. V., Grell, G., Grossi, P., Hansen, A. B., Miranda, A. I., Nopmongcol, U., Prank, M., Sartelet, K. N., Schaap, M., Silver, J. D., Sokhi, R. S., Vira, J., Werhahn, J., Wolke, R., Yarwood, G., Zhang, J., Rao, S. T., and Galmarini, S.: Operational model evaluation for particulate matter in Europe and North America in the context of AQMEII, Atmos. Environ., 53, 75-92, doi:10.1016/j.atmosenv.2012.02.045, 2012.

Stocker, T., Qin, D., Plattner, G., Tignor, M., Allen, S., Boschung, J., Nauels, A., Xia, Y., Bex, V., and Midgley, P.: Climate change 2013: the physical science basis, Contribution of Working Group I to the Fifth Assessment Report of the Intergovernmental Panel on Climate Change, Cambridge University Press, Cambridge, UK, and New York, NY, USA, 1535 pp., 2013.

Textor, C., Schulz, M., Guibert, S., Kinne, S., Balkanski, Y., Bauer, S., Berntsen, T., Berglen, T., Boucher, O., Chin, M., Dentener, F., Diehl, T., Easter, R., Feichter, H., Fillmore, D., Ghan, S., Ginoux, P., Gong, S., Grini, A., Hendricks, J., Horowitz, L., Huang, P., Isaksen, I., Iversen, I., Kloster, S., Koch, D., Kirkevåg, A., Kristjansson, J. E., Krol, M., Lauer, A., Lamarque, J. F., Liu, X., Montanaro, V., Myhre, G., Penner, J., Pitari, G., Reddy, S., Seland, $\varnothing$., Stier, P., Takemura, T., and Tie, X.: Analysis and quantification of the diversities of aerosol life cycles within AeroCom, Atmos. Chem. Phys., 6, 1777-1813, doi:10.5194/acp-6-1777-2006, 2006.
Turquety, S., Menut, L., Bessagnet, B., Anav, A., Viovy, N., Maignan, F., and Wooster, M.: APIFLAME v1.0: high-resolution fire emission model and application to the Euro-Mediterranean region, Geosci. Model Dev., 7, 587-612, doi:10.5194/gmd-7-5872014, 2014.

Vuolo, M. R., Chepfer, H., Menut, L., and Cesana, G.: Comparison of mineral dust layers vertical structures modeled with CHIMERE-DUST and observed with the CALIOP lidar, J. Geophys. Res.-Atmos., 114, D09214, doi:10.1029/2008JD011219, 2009.

Wild, O., Zhu, X., and Prather, J.: Fast-J: accurate simulation of the in- and below-cloud photolysis in tropospheric chemical models, J. Atmos. Chem., 37, 245-282, 2000.

Yu, H., Kaufman, Y. J., Chin, M., Feingold, G., Remer, L. A., Anderson, T. L., Balkanski, Y., Bellouin, N., Boucher, O., Christopher, S., DeCola, P., Kahn, R., Koch, D., Loeb, N., Reddy, M. S., Schulz, M., Takemura, T., and Zhou, M.: A review of measurement-based assessments of the aerosol direct radiative effect and forcing, Atmos. Chem. Phys., 6, 613-666, doi:10.5194/acp-6-613-2006, 2006. 